\title{
Changes in dominance of copepods off Baja California during the 1997-1999 El Niño and La Niña
}

\author{
Luis C. Jiménez-Pérez ${ }^{1}$, Bertha E. Lavaniegos ${ }^{1,2, *}$ \\ ${ }^{1}$ Departamento de Oceanografía Biológica, Centro de Investigación Científica y Educación Superior de Ensenada, \\ km 107 Carretera Tijuana-Ensenada, Apartado Postal 2732, 22860 Ensenada, Baja California, Mexico \\ ${ }^{2}$ Integrative Oceanography Division, Scripps Institution of Oceanography, University of California, San Diego, La Jolla, \\ California 92093-0218, USA
}

\begin{abstract}
Changes in copepod species composition were analyzed from September-October 1997 to April 1999. The community changed substantially between El Niño 1997-1998 and La Niña 19981999, following trends in oceanographic conditions. The warm period was characterized by a community rich in equatorial, tropical/subtropical and warm-temperate cosmopolites, but almost lacking in subarctic copepods. The widespread presence of Undinula vulgaris appears to be due to the strong poleward jet that developed in the coastal region during autumn 1997. Although the coastal jet dispersed in early 1998, the strong influence of equatorial water continued, as indicated by the record abundance of Subeucalanus subtenuis, an equatorial species in oceanic eutrophic waters. The community during the cold period comprised very few copepods with equatorial affinity, few tropical/subtropical and warm-temperate cosmopolites, and an increased relative importance of subarctic species. Copepods typical for the California Current (transition zone group) displayed no significant differences between the extremes of El Niño/La Niña during the fall and winter seasons. A strong La Niña increase in the transition zone group (particularly in Calanus pacificus) was observed until spring 1999, and was probably related to a record coastal upwelling during the La Niña conditions at this time. El Niño 1997-1998 had a greater influence on equatorial species in the region than the previous El Niño event of 1957-1959.
\end{abstract}

KEY WORDS: Copepods $\cdot$ El Niño $\cdot$ La Niña $\cdot$ Baja California $\cdot$ California Current Resale or republication not permitted without written consent of the publisher

\section{INTRODUCTION}

The El Niño event of 1997-1998 and the subsequent La Niña event of 1998-1999 were, respectively, the warm and cold phases of a very strong El Niño Southern Oscillation (ENSO) cycle affecting the Pacific Ocean. Unprecedented surface warming occurred during spring 1997 throughout the tropical eastern Pacific (Webster \& Palmer 1997) due to a weakening and reversal of the trade winds in the western and central equatorial Pacific (McPhaden 1999). The temperature anomalies spread eastward and poleward through a Kelvin wave, reaching the California Current System (CCS) in summer 1997 (Lynn et al. 1998). The El Niño changes in the CCS were characterized by extreme water-mass characteristics and a strengthening and broadening of the poleward nearshore flow from Baja California (Durazo \& Baumgartner 2002), along the coasts of California (Collins et al. 2002, Lynn \& Bograd 2002) and Oregon (Huyer et al. 2002).

Although the physical evolution of El Niño showed a clear extention eastward along the equatorial Pacific, and poleward in the CCS, the biological response displayed notable regional differences throughout the ENSO cycle. Nutrients and chlorophyll decreased sharply in the equatorial Pacific (Chavez et al. 1999) and relatively strongly in central California (Chavez et al. 2002), Oregon (Corwith \& Wheeler 2002), and the Gulf of Alaska (Whitney \& Welch 2002). In contrast, in southern California and Baja California chlorophyll remained within the usual range of values (Hayward 2000, Lavaniegos et al. 2002). Moderate phytoplankton blooms were observed off Baja California (Kahru \& Mitchell 2000).

Low zooplankton biomass was recorded during El Niño 1997-1998 along transect line P (from Vancouver 
Island to $50^{\circ} \mathrm{N}, 145^{\circ} \mathrm{W}$ ), off the Canadian coast (Mackas \& Galbraith 2002) and off southern California (Hayward 2000, Lavaniegos \& Ohman 2003). In contrast, relatively high zooplankton biomass was observed off Baja California during the warm phase of the ENSO, sustained mainly by the presence of salp blooms (Lavaniegos et al. 2002). Evidence of reduced populations of copepods and euphausiids with affinity to cold-temperate water has been provided for Line $\mathrm{P}$ (Mackas \& Galbraith 2002), Oregon (Peterson et al. 2002), Monterey Bay (Hopcroft et al. 2002, Marinovic et al. 2002) and the Southern California Bight and its offshore region (Rebstock 2002). Simultaneously, some subtropical species occurred in northern sectors of the CCS, such as the euphausiid Nyctiphanes simplex, the hyperiid amphipod Primno brevidens and the copepods Acartia danae and Eucalanus hyalinus (Mackas \& Galbraith 2002, Tanasichuk \& Cooper 2002).

The invasion of subtropical taxa did not persist. The 1997-1998 El Niño was short, rapidly switching from warm to cold conditions through spring of 1998. An abrupt intensification of the easterly trade winds over the eastern equatorial Pacific Ocean (McPhaden \& Yu 1999) combined with the already shallow equatorial thermocline in the central and eastern Pacific Ocean (Takayabu et al. 1999) marked the onset of La Niña. In the CCS, the weakening of El Niño occurred in April 1998 with the disappearance of the Inshore Countercurrent and extreme reduction in deep poleward transport (Collins et al. 2002, Lynn \& Bograd 2002), with early 1999 marking the peak of La Niña. A record coastal upwelling occurred in the spring and summer of 1999 throughout much of the CCS (Schwing et al. 2000), which promoted high chlorophyll concentrations (Hayward et al. 1999, Chavez et al. 2002, Corwith \& Wheeler 2002, Lavaniegos et al. 2002, Wilkerson et al. 2002).

Similarly to chlorophyll, zooplankton biomass increased in southern California (Hayward 2000, Lavaniegos \& Ohman 2003) and Monterey (Marinovic et al. 2002), but not in Baja California, where biomass decreased with the diminution in tunicate blooms (Lavaniegos et al. 2002). In 1999, the expected recovery of the boreal copepod populations off Oregon was observed (Peterson et al. 2002), but not the typical springtime dominance of large-bodied copepods in Monterey Bay (Hopcroft et al. 2002), although in both areas subtropical species decreased during La Niña. The trends for euphausiids were the expected resurgence of subarctic Euphausia pacifica and Thysanoessa spinifera in spring and summer of 1999, while the subtropical Nyctiphanes simplex was completely absent in the Monterey area as usual (Marinovic et al. 2002).

Biological responses to the oceanic events of 1997 to 1999 show interesting differences in the region off Baja California. This most southern sector of the CCS has the greatest tropical influence, but has been studied less than the other sectors. The Baja California area appears to be a source-region for species that expand their ranges northward during warm events, but little is known about how these species respond within their own home range. The purpose of the present study was to analyze the changing species composition of copepods during El Niño 1997-1998 and La Niña 19981999 in the oceanic ecosystem off Baja California.

\section{MATERIALS AND METHODS}

Study area and sampling. The California Current System (CCS) is a dynamic system formed by the mixing of Pacific Subarctic, North Pacific Central, and Equatorial Pacific water masses, and coastal upwelled water (Lynn \& Simpson 1987). The surface currents of the CCS show seasonal variability, with a weakening of the main current flowing to the equator and the development of the coastal countercurrent during fall and winter (Hickey 1979, Lynn \& Simpson 1987). The California Undercurrent is less well known, but apparently undergoes changes in intensity similar to those in the coastal countercurrent. In the present study, the sampling site was in the southernmost sector of the CCS.

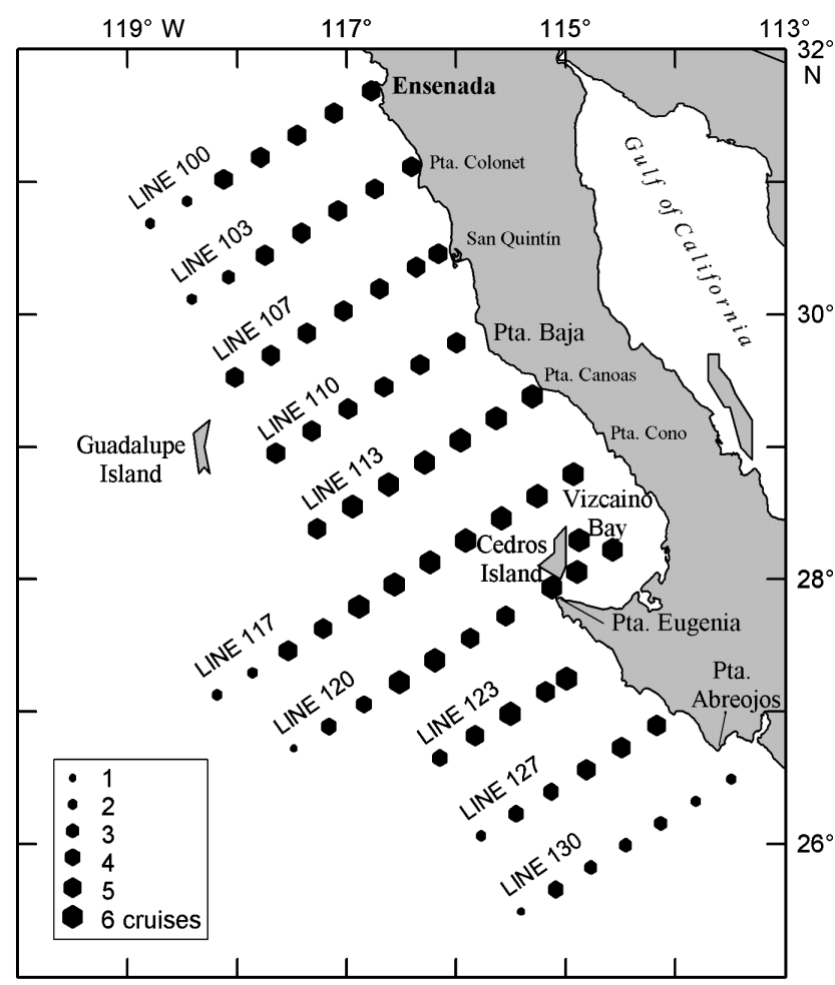

Fig. 1. Sampling stations of IMECOCAL cruises during 1997 to 1999. Symbols indicate number of cruises (i.e. number of times sampled). IMECOCAL cruises are based on the same positions and nomenclature of the CalCOFI cruises 
Temperature data were taken with CTD casts during 6 IMECOCAL (Investigaciones Mexicanas de la Corriente de California) cruises designated 9710 (September-October 1997), 9801 (January-February 1998), 9807 (July 1998), 9810 (September-October 1998), 9901 (January 1999), and 9904 (April 1999). The cruises were conducted on the RV 'Francisco de Ulloa'. The station grid consisted of 10 lines approximately perpendicular to the coast, corresponding to CalCOFI transect lines 100 through 130 (Fig. 1). On Cruise 9710 only transect lines 110 to 127 were sampled. Transect 127 was missing during Cruise 9901, and transect 130 during Cruises 9810 and 9901.

Zooplankton was collected with a $61 \mathrm{~cm}$ diameter bongo net of $505 \mu \mathrm{m}$ mesh-width. Oblique tows were done from $210 \mathrm{~m}$ to the surface when bottom depth permitted and from $10 \mathrm{~m}$ above the bottom to the surface at shallow stations. The volume of water strained was measured with a flowmeter in the mouth of the net (Smith \& Richardson 1977). A total of 342 zooplankton samples were collected. Subsamples of $1 / 8$ or $1 / 16$ of the original samples were taken using a Folsom splitter. Adult copepods in the subsample were identified to species after Grice (1961), Brodsky (1967), Geletin
(1976), Dawson \& Knatz (1980) and Palomares et al. (1998).

Data processing. In order to adjust for seasonal variability of temperature and salinity, the seasonal means of the period 1950 to 1978 were subtracted to calculate temperature and salinity anomalies in the IMECOCAL cruises. These historical means were estimated by Lynn et al. (1982) from the CalCOFI data for the Baja California region. This procedure was done for temperatures (or salinities) at 10 and $150 \mathrm{~m}$ depth for transect lines 110 and 120 . For some line stations (110.45, $110.55,120.40,120.55,120.65)$ the seasonal mean was extrapolated using data from the nearest stations. For IMECOCAL Cruise 9904 Stns 110.35 to 110.50 were missing; therefore data from Stns 107.35 to 107.50 were used instead.

Copepod abundance was standardized to individuals $\mathrm{m}^{-3}$. In this study only dominant species were considered, defined as those species present in $50 \%$ of the samples in 1 or more cruises. The species abundances were converted to carbon biomass based on lengthcarbon (C), length-dry weight (DW), or length-ash free dry weight (AFDW) regressions from the literature (Table 1). DW and AFDW were converted to carbon

Table 1. Length-weight regressions for copepod species used to estimate carbon (C), ash-free dry weight (AFDW) and dry weight (DW). PL: prosome length, TL: total length. Length parameter not indicated when a regression was not available and female weight was used instead

\begin{tabular}{|c|c|c|c|c|}
\hline Species & Length parameter & \multicolumn{2}{|c|}{ Regression for female weight } & Source \\
\hline Acartia clausi ${ }^{\mathrm{a}}$ & PL & \multicolumn{2}{|c|}{$\log \mu g C=3.08(\log \mu \mathrm{m})-8.51$} & Uye (1982) \\
\hline Calanus pacificus ${ }^{\mathrm{b}}$ & PL & \multicolumn{2}{|c|}{$\ln \mu \mathrm{g} D W=2.5(\ln \mathrm{mm})+2.99$} & Runge (1980) \\
\hline Candacia/Paracandacia & PL & \multicolumn{2}{|c|}{$\ln \mu \mathrm{g} D W=3.38(\ln \mu \mathrm{m})-20.48$} & Webber \& Roff (1995) \\
\hline Centropages furcatus ${ }^{\mathrm{C}}$ & PL & \multicolumn{2}{|c|}{$\ln \mu \mathrm{g} C=3.82(\ln \mu \mathrm{m})-24.58$} & Satapoomin (1999) \\
\hline Clausocalnus furcatus $^{\mathrm{d}}$ & PL & \multicolumn{2}{|c|}{$\ln \mu \mathrm{g} D W=3.68(\ln \mu \mathrm{m})-22.86$} & Chisholm \& Roff (1990) \\
\hline Eucalanus californicus ${ }^{\mathrm{e}}$ & PL & \multicolumn{2}{|c|}{$\log \mu \mathrm{g} D W=3.09(\log \mathrm{mm})-0.0026$} & Hopcroft et al. (2002) \\
\hline Subeucalanus pileatus ${ }^{\mathrm{f}}$ & & \multicolumn{2}{|c|}{$36.97 \mu \mathrm{gC}$} & Tester \& Turner (1988) \\
\hline Euchaeta spp. & PL & \multicolumn{2}{|c|}{$\ln \mu \mathrm{g} C=3.82(\ln \mu \mathrm{m})-25.19$} & Satapoomin (1999) \\
\hline Haloptilus longicornis & PL & \multicolumn{2}{|c|}{$\ln \mu \mathrm{g} D W=4.27(\ln \mu \mathrm{m})-29.00$} & Webber \& Roff (1995) \\
\hline Heterorhabdus tanneri ${ }^{g}$ & PL & \multicolumn{2}{|c|}{$\log \mu \mathrm{g}$ AFDW $=3.463(\log \mathrm{mm})+0.943$} & Yamaguchi \& Ikeda (2000) \\
\hline Labidocera trispinosa ${ }^{\mathrm{h}}$ & & \multicolumn{2}{|l|}{$33 \mu \mathrm{g} \mathrm{C}$} & Barnett (1974) \\
\hline Mesocalanus tenuicornis & & \multicolumn{2}{|l|}{$23.29 \mu \mathrm{g} \mathrm{C}$} & Lindley et al. (1997) \\
\hline Metridia pacifica & & \multicolumn{2}{|l|}{$101 \mu \mathrm{g}$ DW } & Ohman (1988) \\
\hline Paracalanus parvus & PL & \multicolumn{2}{|c|}{$\ln \mu \mathrm{g} D W=2.78(\ln \mu \mathrm{m})-16.52$} & Webber \& Roff (1995) \\
\hline Pleuromamma scutullata ${ }^{\mathrm{i}}$ & PL & \multicolumn{2}{|c|}{$\log \mu \mathrm{g}$ AFDW $=2.812(\log \mathrm{mm})+1.09$} & Yamaguchi \& Ikeda (2000) \\
\hline Rhincalanus nasutus & TL & \multicolumn{2}{|c|}{$\log \mu \mathrm{g} C=4.30(\log \mathrm{mm})-0.47$} & Mullin \& Brooks (1967) \\
\hline Scolecithrix danae ${ }^{\mathrm{j}}$ & PL & \multicolumn{2}{|c|}{$\ln \mu \mathrm{g} D W=3.57(\ln \mu \mathrm{m})-21.36$} & Webber \& Roff (1995) \\
\hline Temora discaudata & PL & \multicolumn{2}{|c|}{$\ln \mu \mathrm{g} C=3.55(\ln \mu \mathrm{m})-22.07$} & Satapoomin (1999) \\
\hline Undinula vulgaris ${ }^{\mathrm{k}}$ & PL & \multicolumn{2}{|c|}{$\ln \mu \mathrm{g} D W=3.65(\ln \mu \mathrm{m})-22.89$} & Chisholm \& Roff (1990) \\
\hline Oithona plumifera & PL & \multicolumn{2}{|c|}{$\log \mu \mathrm{g}$ AFDW $=3.16(\log \mu \mathrm{m})-8.30$} & Hopcroft et al. (1998) \\
\hline Corycaeus spp. ${ }^{1}$ & PL & \multicolumn{2}{|c|}{$\log \mu \mathrm{g}$ AFDW $=2.80(\log \mu \mathrm{m})-7.17$} & Hopcroft et al. (1998) \\
\hline \multirow{6}{*}{\multicolumn{3}{|c|}{$\begin{array}{l}\text { a Applied to A. danae and A. negligens in present study } \\
\text { bA Also used for Nannocalanus minor, Neocalanus cristatus, Neo- } \\
\text { Calanus gracilis, and Aetidius bradyi in present study } \\
\text { cAlso used for C. bradyi and C. elongatus in present study } \\
\text { da Applied to Clausocalanus spp. in present study } \\
\text { eAlso used for E. hyalinus and Pareucalanus attenuatus in present } \\
\text { study }\end{array}$}} & \multicolumn{2}{|c|}{${ }^{g}$ Applied to $H$. papilliger in present study } \\
\hline & & & \multicolumn{2}{|c|}{$\begin{array}{l}{ }^{\mathrm{h}} \text { Applied to } L \text {. acutifrons in present study } \\
{ }^{\mathrm{A}} \text { Applied to } P \text { abdominalis } P \text { borealis } P \text { aracilis } P \text { piseki and }\end{array}$} \\
\hline & & & \multicolumn{2}{|c|}{$\begin{array}{l}{ }^{\mathrm{i}} \text { Applied to } P \text {. abdominalis, } P \text {. borealis, } P \text {. gracilis, } P \text {. piseki, and } \\
\text { Lucicutia flavicornis in present study }\end{array}$} \\
\hline & & & \multicolumn{2}{|c|}{${ }^{\mathrm{j} A l s o}$ used for $S$. bradyi and Scolecithricella ovata in present study } \\
\hline & & & \multicolumn{2}{|c|}{${ }^{\mathrm{k}}$ Also used for $U$. darwini in present study } \\
\hline & & & \multicolumn{2}{|c|}{$\begin{array}{l}{ }^{1} \text { Also used for Copilia mirabilis and Sapphirina nigromaculata in } \\
\text { present study }\end{array}$} \\
\hline
\end{tabular}




\section{Sampling Stations}

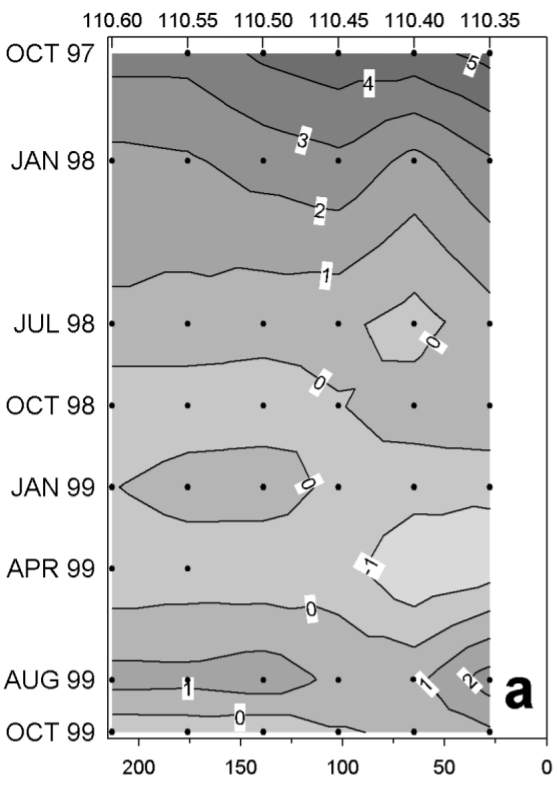

$\begin{array}{llllll}110.60 & 110.55 & 110.50 & 110.45 & 110.40 & 110.35\end{array}$

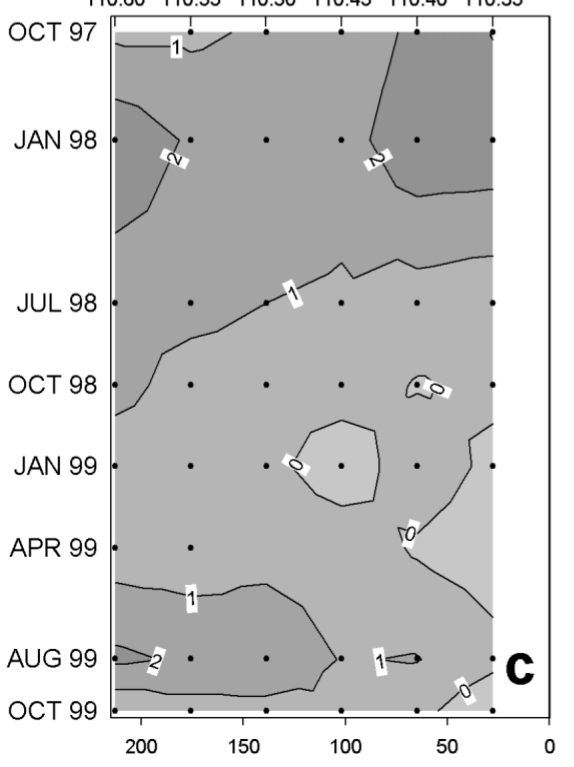

$\begin{array}{lllllllll}120.70 & 120.65 & 120.60 & 120.55 & 120.50 & 120.45 & 120.40 & 120.35 & 120.30\end{array}$

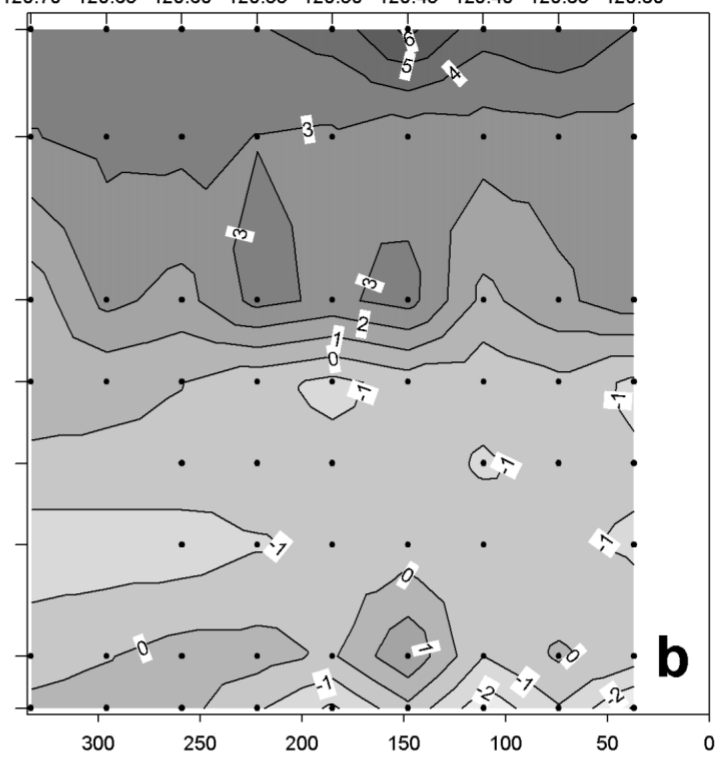

Fig. 2. Time-distance plots of temperature anomalies $\left(-2\right.$ to $\left.6^{\circ} \mathrm{C}\right)$ at $(\mathrm{a}, \mathrm{b}) 10 \mathrm{~m}$ and $(\mathrm{c}, \mathrm{d})$ $150 \mathrm{~m}$ for stations along $(\mathrm{a}, \mathrm{c}) \quad$ transect line 110 and $(b, d)$ transect line 120 (see Fig. 1). Anomalies estimated by $X_{i}-X$, where $X_{i}$ is value measured during 1 IMECOCAL cruise and $X$ is seasonal mean for the period 1950 to 1978
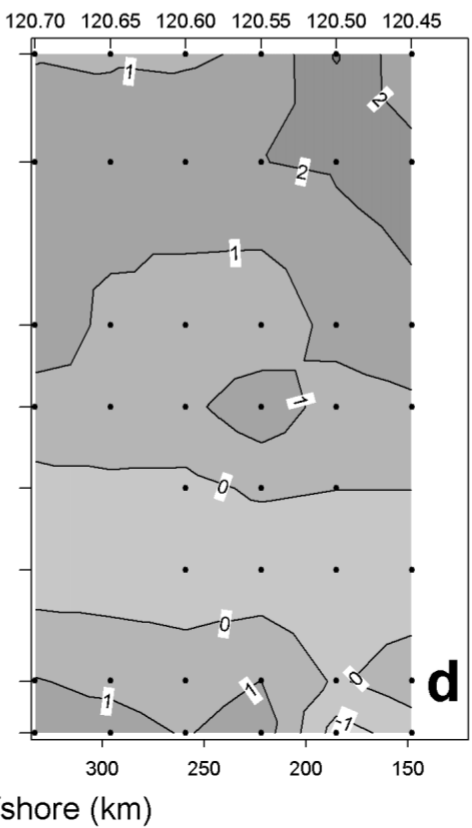

to our data. The CalCOFI cruises selected were Cruises 5810 and 5901 (the stations on transect lines 100 and 120 in Fig. 1), and the IMECOCAL cruises were Cruises 9710 (transect lines 110 and 120) and 9801 (transect lines 100, 110, 120, 130).

The species were arranged in biogeographic groups based on previous studies for the Pacific Ocean (Brodsky 1967, 1975, Fleminger 1967, 1973, 1975, Park 1968, 1995, Nishida 1985, Brinton et al. 1986, US GLOBEC 1994). The category subarctic is defined in the present study as the faunal group inhabiting mainly the subarctic zone, and the category transition zone is the group mostly abundant in the CCS. Tropical/subtropical and equatorial groups are both found in the tropics sensu stricto, but the

assuming that carbon corresponds to $50 \%$ DW and $45 \%$ AFDW. Abundance and carbon-content data were $\log (x+1)$-transformed before calculating the mean and $95 \%$ confidence interval. Statistical comparisons between pair of cruises were done using the Mann-Whitney $U$-test on raw data from nighttime samples. The results of the $U$-test will be expressed as z (normal approximation).

Additional comparisons were made between the 1997-1998 El Niño and the previous 1957-1959 El Niño. Ranks-of-abundance categories were assigned from distribution charts of calanoid species from Fleminger $(1964,1967)$ and compared with similar ranks applied tropical/subtropical group differs from the equatorial group in that it also occurs in subtropical regions. The warm-temperate group is widespread throughout the tropical and temperate regions.

\section{RESULTS}

\section{Thermohaline anomalies}

Temperature at $10 \mathrm{~m}$ depth peaked in October 1997 , with a mean and standard deviation of $24.4 \pm 0.9^{\circ} \mathrm{C}$. In January 1998 the mean temperature decreased to 18.7 $\pm 1.1^{\circ} \mathrm{C}$, but positive temperature anomalies of 2 to $6^{\circ} \mathrm{C}$ 


\section{Sampling Stations}
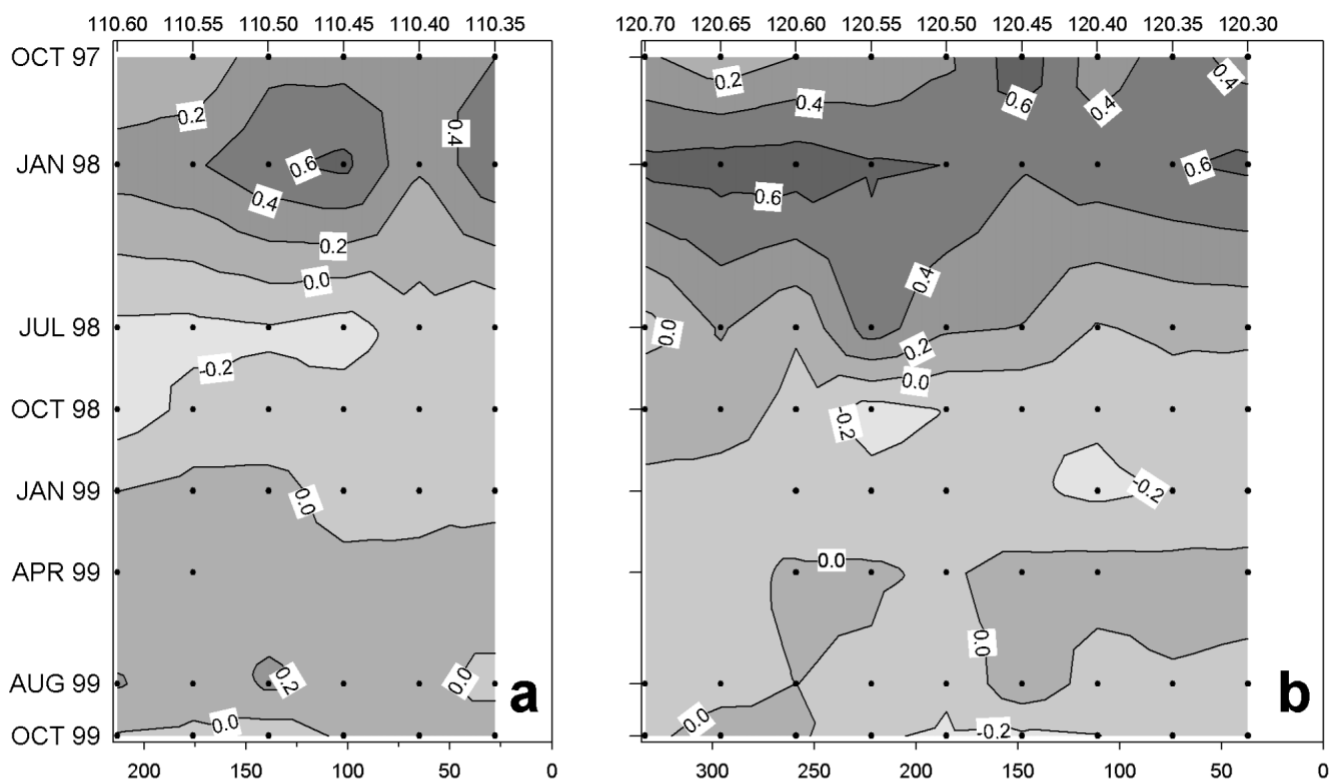

Fig. 3. Time-distance plots of salinity anomalies $(-0.2$ to 0.6$)$ at $(\mathrm{a}, \mathrm{b}) 10 \mathrm{~m}$ and $(\mathrm{c}, \mathrm{d})$ $150 \mathrm{~m}$ for stations along $(\mathrm{a}, \mathrm{c})$ transect line 110 and $(b, d)$. Further details as in Fig. 2

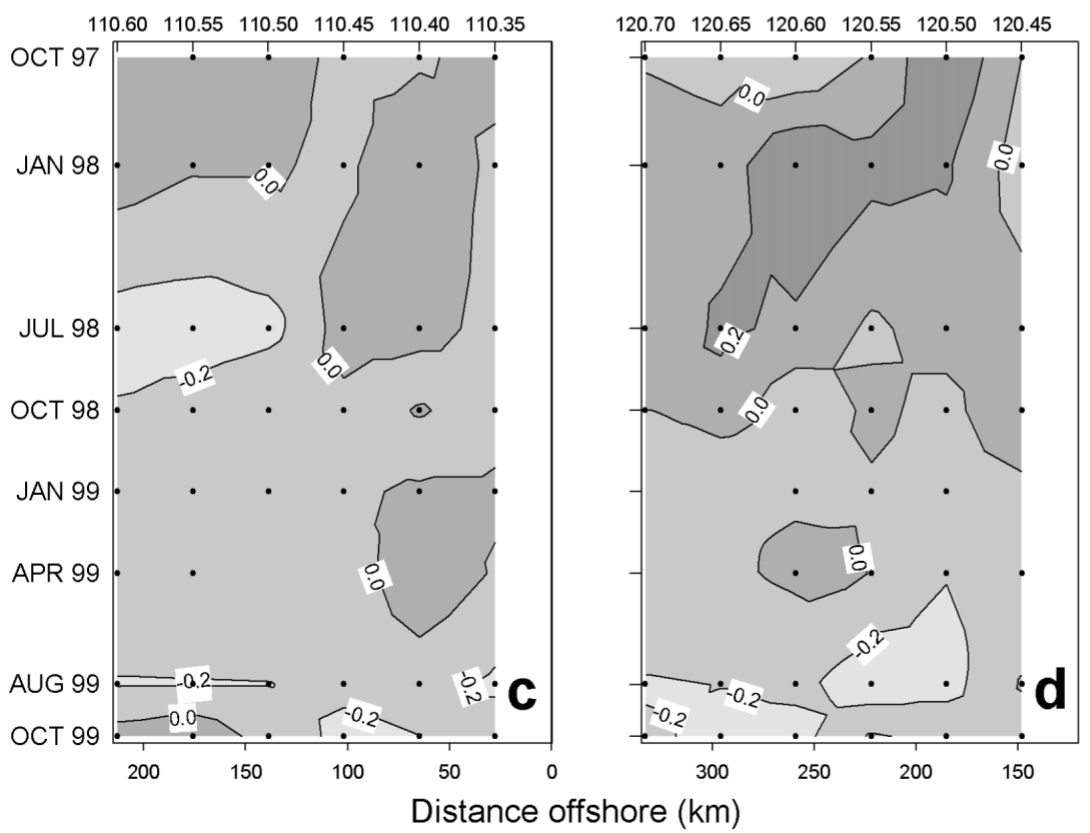

stronger in the southern part of the area. The influence of La Niña extended throughout 1999.

Small positive anomalies in August 1999 (Fig. 2) must be considered overestimations as the seasonal means used in the calculations were from CalCOFI cruises in July instead of August, and seasonal warming is usually high between these months. An additional problem is the absence of reference data for the period 1979 to 1997. Our anomalies could have been artefactually increased due to decadal warming in the northeast Pacific after 1977 (Mantua et al. 1997).

Salinity anomalies followed a trend similar to that of temperature, being positive during the warm phase and zero to negative in the cool phase (Fig. 3). The extension of the positive

indicated that both October 1997 and January 1998 were strongly influenced by El Niño (Fig. 2a,b). The anomalous warming affected a relatively thick upper layer, as anomalies as high as $3^{\circ} \mathrm{C}$ were recorded at $150 \mathrm{~m}$ depth (Fig. 2c,d).

By July 1998, temperature anomalies had dissipated for transect line 110 at $10 \mathrm{~m}$ depth, but remained as high as $3^{\circ} \mathrm{C}$ for line 120 (Fig. 2a,b). Along both transect lines, anomalies at some stations at $150 \mathrm{~m}$ surpassed $1^{\circ} \mathrm{C}$ (Fig. 2c,d). By October 1998, a rapid and intense cooling occurred along both lines. On transect line 120 the drop in temperature was $3^{\circ} \mathrm{C}$ compared to the previous season (Fig. 2b), indicating that La Niña was anomalies offshore during Cruises 9710 and 9801 indicates that the source was probably not coastal upwelled water. The anomalies were more likely due to Equatorial Pacific water entering the CCS from the west (Lynn \& Simpson 1987).

In July 1998, an intrusion of low-salinity (subarctic) water was observed along transect line 110 (Fig. 3a), but only at the most offshore station on transect line 120 (Fig. 3b). This low-salinity core was present even at $150 \mathrm{~m}$ on Cruise 9807 (Fig. 3c). Contrary to expectations, few salinity anomalies were found during the first part of 1999, but were observed in August and October in subsurface waters (Fig. 3c,d). 


\section{Copepods}

The total number of copepod species identified was 169 for the complete study period (see Appendix 1). They belonged to the orders Calanoida (70\%), Poecilostomatoida (25\%), Cyclopoida (4\%), and Harpacticoida $(1 \%)$. The only genus not identified to species was Clausocalanus. Copepodites of different genera were also present in samples, but those of Euchaeta and Candacia were particularly abundant. Considering as dominant species those collected in $50 \%$ or more samples during one or more cruises, the number is reduced to 47 plus Clausocalanus spp. (Table 2).

Dominant species (ordered by biogeographic groups) displayed changing proportions through the warm period (Cruises 9710 and 9801), the transition phase (Cruise 9807), and the cool period (Cruises 9810, 9901, and 9904). An unusually low percentage of Transition Zone copepods (9\%) was recorded in fall 1997 compared to Equatorial, Tropical/Subtropical, and warm-temperate groups which, combined, comprised $90 \%$ of the total (Fig. 4a). The percentages are based

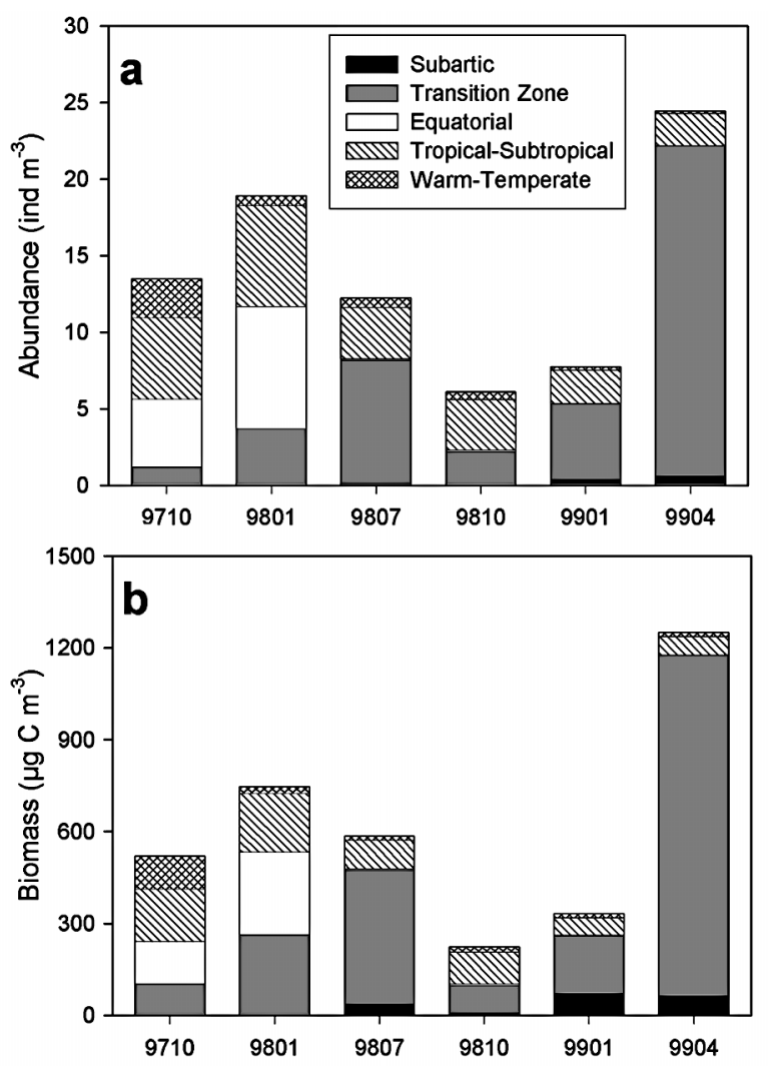

Fig. 4. Proportional contribution of biogeographic groups of copepods as (a) abundance and (b) carbon biomass, in nighttime samples, averaged per cruise. Proportions are based on anti-log means. Abscissa shows 6 IMECOCAL cruises (9710: Sep-Oct 1997; 9801: Jan-Feb 1998; 9807: Jul 1998; 9810 Sep-Oct 1998; 9901: Jan 1999; 9904: Apr 1999) on mean abundances (antilogged mean) from nighttime samples. With regard to the biomass of the Transition Zone group, their importance increases considerably $(20 \%)$, but remained low relative to their usual dominance in the California Current (Fig. 4b). During winter of 1998 the Equatorial and Transition Zone copepods increased in abundance to 19 and $42 \%$, respectively, corresponding to 35 and $36 \%$ of the biomass.

In July 1998, the Equatorial group virtually disappeared while the Transition Zone group dominated the copepod community (65\% of abundance and $74 \%$ of biomass). The Subarctic component was small (6\% of the copepod biomass). The seasonal change was stronger than usual due to the extraordinarily warm winter of 1998.

Apart from the Tropical/Subtropical group and Clausocalanus spp., the lowest abundance and biomass of copepods occurred at the beginning of La Niña in October 1998. The small contribution of the Equatorial, Tropical/Subtropical, and warm-temperate groups was in sharp contrast to their contribution in the preceding warm fall of 1997 (Fig. 4). Further development of La Niña in January 1999 brought a strong increase in abundance of the Subarctic and Transition Zone copepods (21 and $57 \%$ of the biomass). Again, 9901 abundances were significantly lower than in the previous warm winter of 1998 for the Equatorial $(z=6.61, p<$ $0.001)$ and Tropical/Subtropical $(z=5.49, p<0.001)$ groups. However, for the Transition Zone group no statistical differences were observed in biomass (or abundance) between Cruises 9801 and 9901.

From January to April 1999, the biomass of copepods increased from 331 to $1250 \mu \mathrm{g} \mathrm{C} \mathrm{m}^{-3}$ (antilogged mean), due mainly to the Transition Zone group, which increased 6-fold (Fig. 4b). Proportions of the biogeographic groups were completely inverse to those observed at the beginning of the sampling period. The Transition Zone and Subarctic groups combined represented $94 \%$ of the total copepods on Cruise 9904.

\section{Species with limited distribution}

The distribution of species is dynamic, but certainly some species are more stenothermal than others, with greater affinity for warm or cold waters. This was the case for three of the biogeographic groups:

Subarctic group. These species enter the CCS with cold northern waters. The dominant Subarctic species off Baja California were Neocalanus cristatus and Metridia pacifica (Table 2, Fig. 5). As expected, both species had the lowest biomass in the warm period (Cruises 9710 and 9801). Despite the autumn/winter dormancy of $N$. cristatus, the species was relatively 
Table 2. Dominant copepod species ordered in biogeographic groups, and number of samples in which each was present in IMECOCAL Cruises 9710: Sep-Oct 1997; 9801: Jan-Feb 1998; 9807: Jul 1998; 9810: Sep-Oct 1998; 9901: Jan 1999; 9904 : Apr 1999. OC: oceanic, NE: neritic. Samples collected during night time are in parentheses. Species abbreviations are used in Figs. 5, 8 \& 10

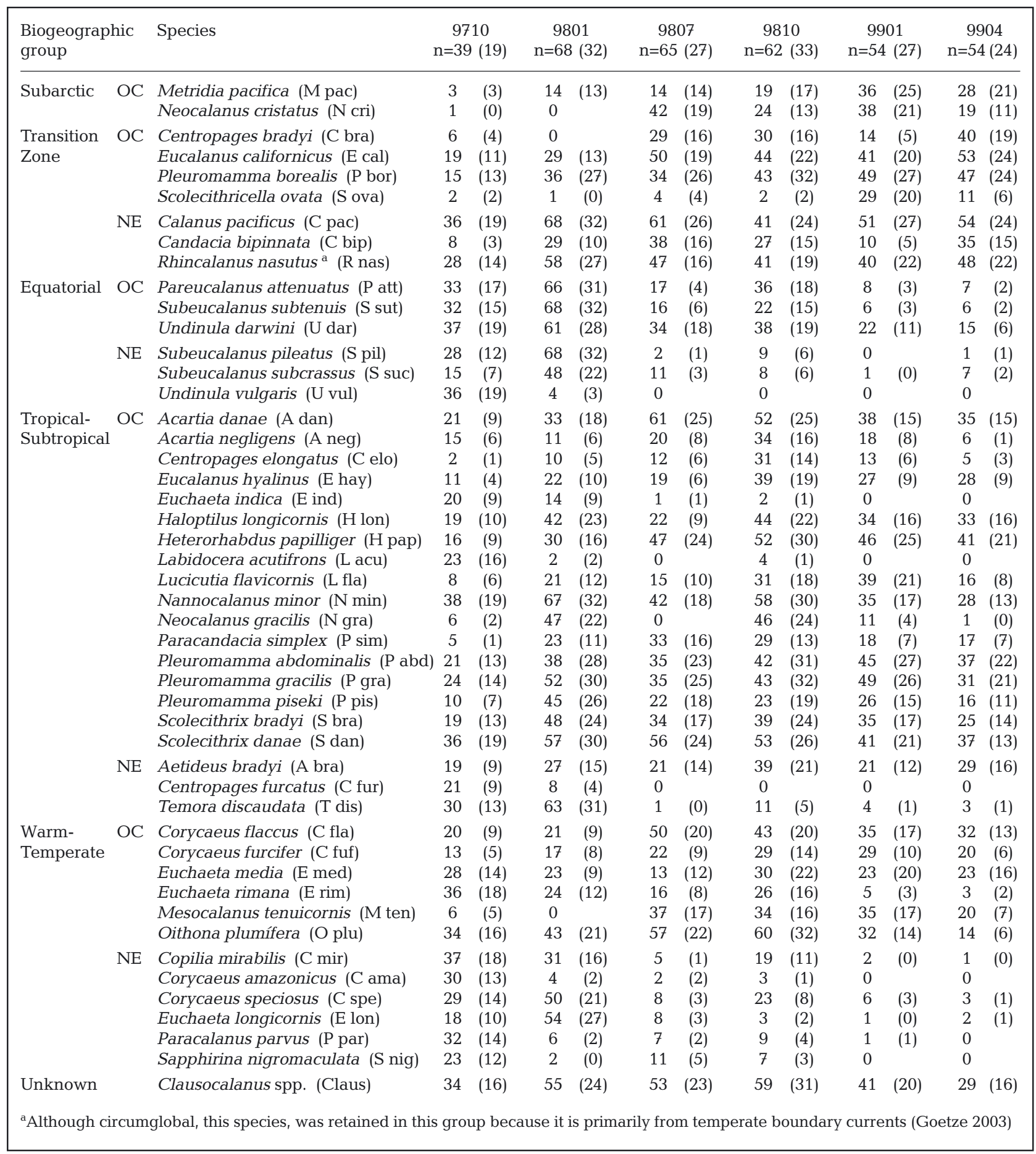

abundant in winter 9901. M. pacifica was more clearly an indicator of La Niña conditions, with higher biomass in January and April 1999.

Transition zone group. This group is associated with the core of the California Current and the coastal upwelling region. Calanus pacificus was the dominant species during Cruises 9807 and 9904 (Fig. 5). Lower captures of $C$. pacificus during fall and winter were probably due to its dormancy in deep waters. Although some samples collected during 1997-1998 contained 


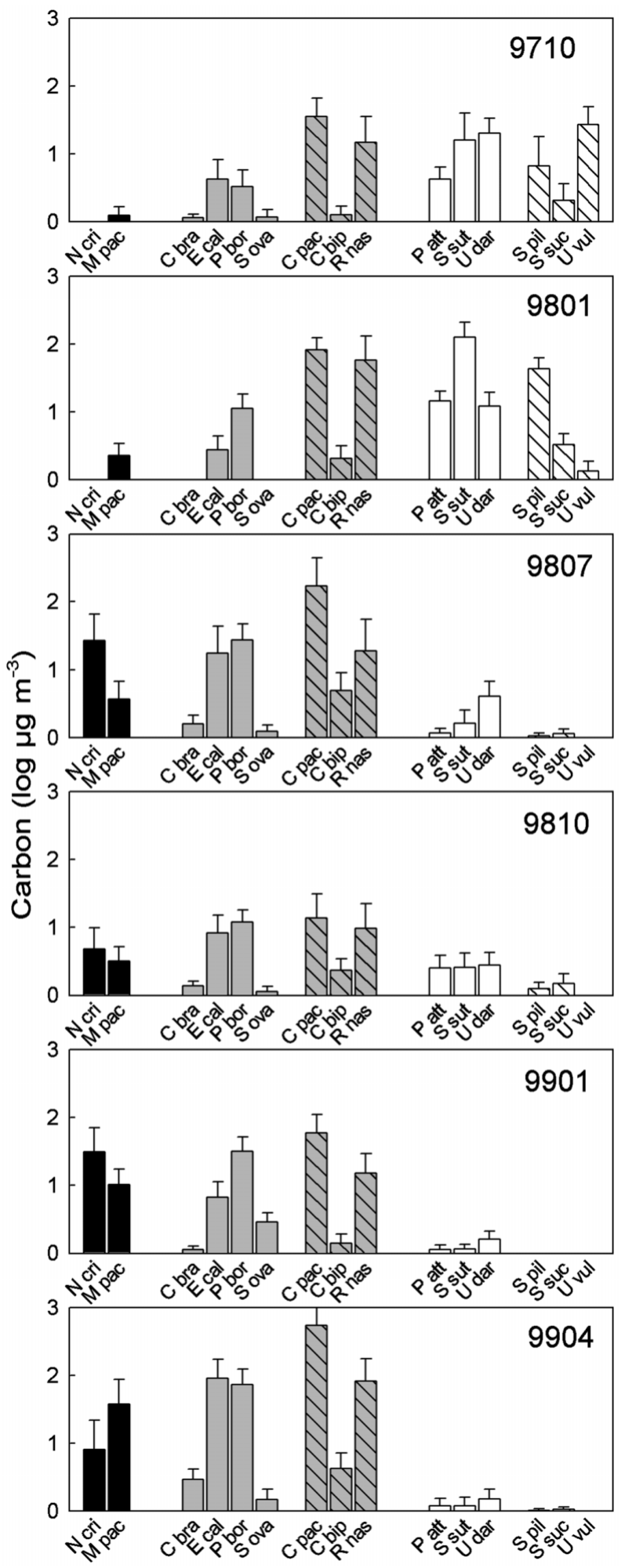

Fig. 5. Carbon biomass (mean $\pm 95 \%$ confidence intervals) of copepod species from 3 biogeographic groups: Subarctic (black bars), Transition zone (gray bars) and Equatorial (white bars), in nighttime samples at IMECOCAL cruises. Hatched bars indicate neritic species, remainder are oceanic. Abbreviations in the abscissa as in Table 2 high numbers of this species, most of the area had relatively low abundance compared to the La Niña spring bloom (see Fig. 9). Other species from this group with maximal capture in April 1999 were Eucalanus californicus, Pleuromamma borealis and Rhincalanus nasutus. The biomass of E. californicus and P. borealis was also significantly higher in the cold winter covered by Cruise 9901 than the winter covered by Cruise 9801 (Table 3). However, R. nasutus had a higher biomass in the warm winter covered by Cruise 9801.

The other 3 species in this group (Candacia bipinnata, Centropages bradyi and Scolecithricella ovata), although very common in the samples from some cruises, made only small contributions to the biomass.

Equatorial group. This group is transported into the region from the southwest with equatorial water. The presence of this group during the warm period was extraordinarily high, representing 27 and $36 \%$ of the copepod biomass during Cruises 9710 and 9801, respectively. The dominant neritic species were Subeucalanus pileatus, S. subcrassus and Undinula vulgaris (Fig. 5). These 3 species were more abundant during the warm period (Table 2). U. vulgaris was the second most abundant species in Cruise 9710, decreasing sharply during Cruise 9801 and disappearing later.

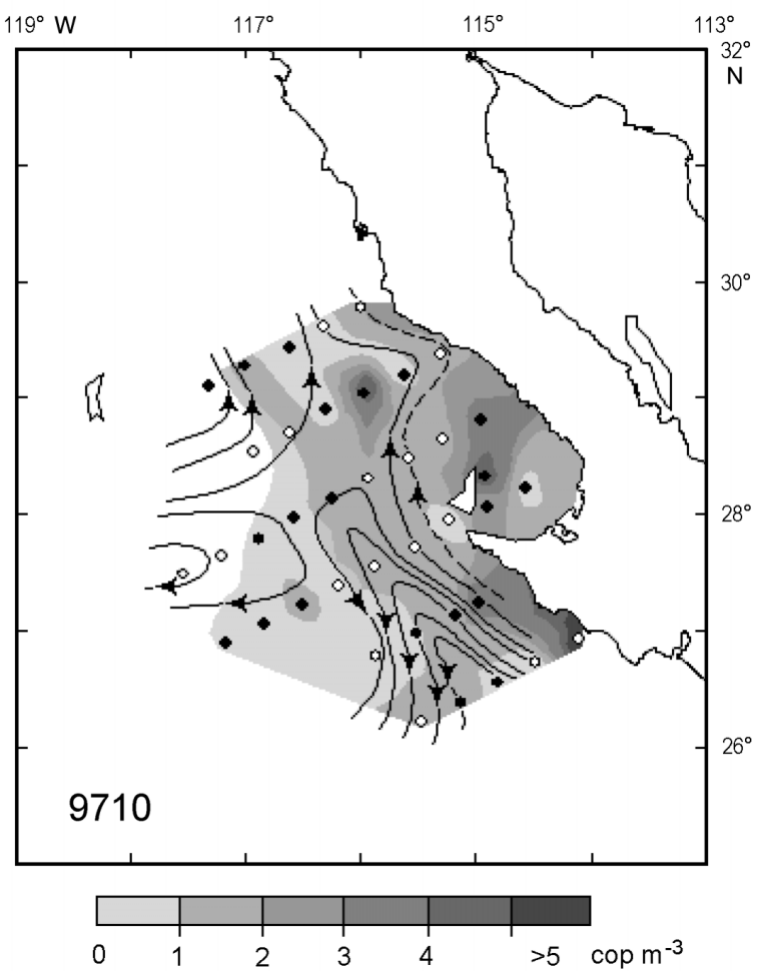

Fig. 6. Undinula vulgaris abundance (copepods $\mathrm{m}^{-3}$ ) during fall 1997 (Cruise 9710). Black (white) circles are stations sampled during night (day). Arrowed lines are dynamic height anomalies (10/500 dbar) redrawn from Lynn et al. (1998) 
Table 3. Comparison of carbon biomass of dominant copepods during fall $(9710,9810)$ and winter $(9801,9901)$ of 2 successive years, using the Mann-Whitney $U$ test. Only the species with significant differences at $\alpha=0.05$ are shown. Ratio of fall (9710/9810) and winter (9801/9901) medians is indicated when medians are higher than zero. Only nighttime samples were considered. (c: median from warm period $=0$; w: median from cool period $=0$; --: median in both periods $=0$ )

\begin{tabular}{|c|c|c|c|c|c|c|c|c|}
\hline \multirow{2}{*}{$\begin{array}{l}\text { Biogeographic } \\
\text { group }\end{array}$} & \multirow{2}{*}{\multicolumn{2}{|c|}{ Species }} & \multicolumn{3}{|c|}{9710 vs 9810} & \multicolumn{3}{|c|}{9801 vs 9901} \\
\hline & & & $\mathrm{z}$ & $\mathrm{p}$ & ratio & $\mathrm{z}$ & p & ratio \\
\hline Subarctic & $\mathrm{OC}$ & $\begin{array}{l}\text { Metridia pacifica } \\
\text { Neocalanus cristatus }\end{array}$ & $\begin{array}{l}-2.59 \\
-3.09\end{array}$ & $\begin{array}{l}0.023 \\
0.018\end{array}$ & $\begin{array}{l}\mathrm{C} \\
\mathrm{C}\end{array}$ & $\begin{array}{l}-4.19 \\
-5.97\end{array}$ & $\begin{array}{l}<0.001 \\
<0.001\end{array}$ & $\begin{array}{l}\mathrm{C} \\
\mathrm{C}\end{array}$ \\
\hline $\begin{array}{l}\text { Transition } \\
\text { Zone }\end{array}$ & $\mathrm{OC}$ & $\begin{array}{l}\text { Eucalanus californicus } \\
\text { Pleuromamma borealis } \\
\text { Scolecithricella ovata }\end{array}$ & $\begin{array}{r}-1.45 \\
-3.35 \\
0.58\end{array}$ & $\begin{array}{l}0.161 \\
0.001 \\
0.792\end{array}$ & 0.2 & $\begin{array}{l}-2.51 \\
-2.83 \\
-5.77\end{array}$ & $\begin{array}{r}0.016 \\
0.004 \\
<0.001\end{array}$ & $\begin{array}{c}\mathrm{C} \\
0.4 \\
\mathrm{C}\end{array}$ \\
\hline & NE & Rhincalanus nasutus & 0.91 & 0.386 & & 2.60 & 0.009 & 4.6 \\
\hline Equatorial & $\mathrm{OC}$ & $\begin{array}{l}\text { Pareucalanus attenuatus } \\
\text { Subeucalanus subtenuis } \\
\text { Undinula darwini }\end{array}$ & $\begin{array}{l}2.15 \\
3.33 \\
4.71\end{array}$ & $\begin{array}{r}0.034 \\
0.001 \\
<0.001\end{array}$ & $\begin{array}{c}5.7 \\
\mathrm{w} \\
16.0\end{array}$ & $\begin{array}{l}6.54 \\
6.91 \\
5.21\end{array}$ & $\begin{array}{l}<0.001 \\
<0.001 \\
<0.001\end{array}$ & $\begin{array}{l}\mathrm{w} \\
\mathrm{w} \\
\mathrm{W}\end{array}$ \\
\hline & NE & $\begin{array}{l}\text { Subeucalanus pileatus } \\
\text { Subeucalanus subcrassus } \\
\text { Undinula vulgaris }\end{array}$ & $\begin{array}{l}3.65 \\
1.44 \\
6.90\end{array}$ & $\begin{array}{r}0.002 \\
0.282 \\
<0.001\end{array}$ & $\begin{array}{l}\mathrm{w} \\
\mathrm{w}\end{array}$ & $\begin{array}{l}6.81 \\
5.18 \\
1.62\end{array}$ & $\begin{array}{r}<0.001 \\
<0.001 \\
0.540\end{array}$ & $\begin{array}{l}\mathrm{w} \\
\mathrm{w}\end{array}$ \\
\hline $\begin{array}{l}\text { Tropical- } \\
\text { Subtropical }\end{array}$ & $\mathrm{OC}$ & $\begin{array}{l}\text { Acartia danae } \\
\text { Centropages elongatus } \\
\text { Eucalanus hyalinus } \\
\text { Euchaeta indica } \\
\text { Heterorhabdus papilliger } \\
\text { Labidocera acutifrons } \\
\text { Lucicutia flavicornis } \\
\text { Nannocalanus minor } \\
\text { Neocalanus gracilis } \\
\text { Pleuromamma piseki } \\
\text { Scolecithrix bradyi } \\
\text { Scolecithrix danae }\end{array}$ & $\begin{array}{r}-2.94 \\
-2.21 \\
-2.44 \\
2.69 \\
-2.54 \\
5.89 \\
-1.78 \\
4.21 \\
-3.66 \\
-0.42 \\
1.14 \\
2.13\end{array}$ & $\begin{array}{r}0.003 \\
0.027 \\
0.014 \\
0.007 \\
0.011 \\
<0.001 \\
0.103 \\
<0.001 \\
<0.001 \\
0.706 \\
0.265 \\
0.032\end{array}$ & $\begin{array}{c}\mathrm{C} \\
-- \\
\mathrm{C} \\
-- \\
\mathrm{C} \\
\mathrm{W} \\
\mathrm{C} \\
4.8 \\
\mathrm{C} \\
\\
\\
2.0\end{array}$ & $\begin{array}{r}0.78 \\
-0.54 \\
0.00 \\
2.95 \\
-2.84 \\
-2.75 \\
-2.75 \\
6.59 \\
3.68 \\
3.74 \\
2.25 \\
3.69\end{array}$ & $\begin{array}{r}0.463 \\
0.723 \\
1.000 \\
0.064 \\
0.005 \\
0.689 \\
0.008 \\
<0.001 \\
0.001 \\
<0.001 \\
0.026 \\
<0.001\end{array}$ & $\begin{array}{c}0.1 \\
\mathrm{C} \\
38.7 \\
\mathrm{~W} \\
6.4 \\
4.2 \\
3.0\end{array}$ \\
\hline & $\mathrm{NE}$ & $\begin{array}{l}\text { Centropages furcatus } \\
\text { Temora discaudata }\end{array}$ & $\begin{array}{l}2.82 \\
4.04\end{array}$ & $\begin{array}{r}0.004 \\
<0.001\end{array}$ & $\begin{array}{l}-- \\
\mathrm{w}\end{array}$ & $\begin{array}{l}1.89 \\
6.59\end{array}$ & $\begin{array}{r}0.419 \\
<0.001\end{array}$ & $\mathrm{w}$ \\
\hline $\begin{array}{l}\text { Warm- } \\
\text { Temperate }\end{array}$ & $\mathrm{OC}$ & $\begin{array}{l}\text { Corycaeus flaccus } \\
\text { Euchaeta media } \\
\text { Euchaeta rimana } \\
\text { Mesocalanus tenuicornis } \\
\text { Oithona plumífera }\end{array}$ & $\begin{array}{r}-0.33 \\
1.48 \\
5.03 \\
-1.51 \\
1.32\end{array}$ & $\begin{array}{c}0.763 \\
0.145 \\
<0.001 \\
0.185 \\
0.192\end{array}$ & $\mathrm{w}$ & $\begin{array}{r}-2.39 \\
-2.57 \\
2.62 \\
-5.18 \\
2.27\end{array}$ & $\begin{array}{r}0.029 \\
0.016 \\
0.045 \\
<0.001 \\
0.028\end{array}$ & $\begin{array}{c}\mathrm{C} \\
\mathrm{C} \\
-- \\
\mathrm{C} \\
7.3\end{array}$ \\
\hline & NE & $\begin{array}{l}\text { Copilia mirabilis } \\
\text { Corycaeus amazonicus } \\
\text { Corycaeus speciosus } \\
\text { Euchaeta longicornis } \\
\text { Paracalanus parvus } \\
\text { Sapphirina nigromaculata }\end{array}$ & $\begin{array}{l}5.54 \\
5.07 \\
3.83 \\
3.78 \\
4.59 \\
4.41\end{array}$ & $\begin{array}{r}<0.001 \\
<0.001 \\
<0.001 \\
0.004 \\
<0.001 \\
<0.001\end{array}$ & $\begin{array}{l}\mathrm{w} \\
\mathrm{W} \\
\mathrm{w} \\
\mathrm{W} \\
\mathrm{W} \\
\mathrm{w}\end{array}$ & $\begin{array}{l}4.20 \\
1.31 \\
4.43 \\
6.05 \\
0.48 \\
0.00\end{array}$ & $\begin{array}{r}0.001 \\
0.689 \\
<0.001 \\
<0.001 \\
0.862 \\
1.000\end{array}$ & $\begin{array}{l}\mathrm{w} \\
\mathrm{w}\end{array}$ \\
\hline Unknown & & Clausocalanus spp. & -2.10 & 0.036 & 0.5 & 1.49 & 0.143 & \\
\hline
\end{tabular}

This species was probably introduced from the southeastern Pacific coast and dispersed off Baja California by the strong near-surface poleward coastal jet that developed on Cruise 9710 (Fig. 6).

A similar assemblage of 3 oceanic species (Pareucalanus attenuatus, Subeucalanus subtenuis and Undinula darwini) was also found in the warm period. During Cruise 9801 Subeucalanus subtenuis was the dominant species entering the region with equatorial water (salinity $>34$ at $10 \mathrm{~m}$ ) from the southwest (Fig. 7), and decreasing from July 1998 to the end of the study period.

\section{Species with broad distribution}

Tropical/subtropical group. Species in this group are usual residents of the CCS but maintain relatively low abundances. Most of these species had an equally low biomass in the warm and cold phases of 1997 to 1999 (Fig. 8). However, 2 oceanic species (Nannocalanus minor and Scolecithrix danae) and 1 neritic species (Temora discaudata) increased considerably during El Niño. N. minor was the major species during fall 1997 and the second in importance in winter 1998. On both warm cruises, $N$. minor invaded the coastal 


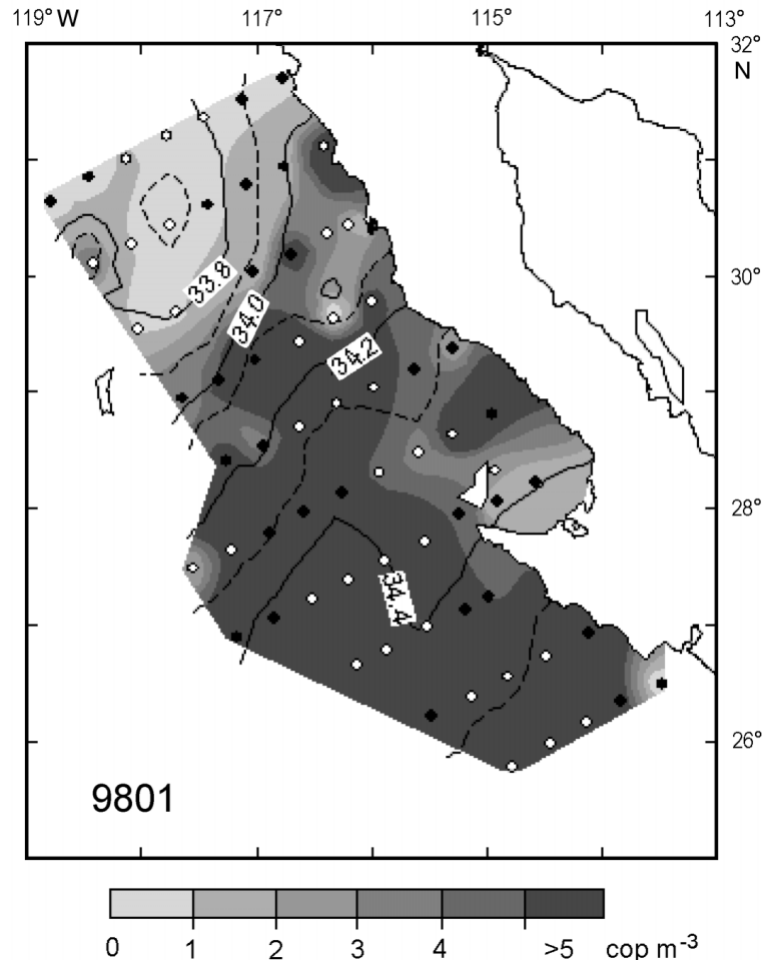

Fig. 7. Subeucalanus subtenuis abundance (copepods $\mathrm{m}^{-3}$ ) during winter 1998 (Cruise 9801). Black (white) circles are stations sampled during night (day). Lines indicate isohalines at $10 \mathrm{~m}$ depth

zone, including Vizcaino Bay (Fig. 9). This bay is partially isolated to the west, and usually remains cooler than the central oceanic region from late summer to early winter. The distributions of $N$. minor and Calanus pacificus displayed opposite patterns, which could reflect interspecific competition. Although some regions of overlap between these species were observed throughout the study period, most locations with a high aggregation of $C$. pacificus had a low abundance of N. minor.

The biomass of Scolecithrix danae was high through 1998, decreasing in 1999. It differed significantly between autumn (Cruises 9710 and 9810) and winter (Cruises 9801 and 9901) (Table 3). Similar levels of biomass were found for 2 species of Pleuromamma ( $P$. abdominalis and $P$. gracilis), which remained the same throughout the study period. In contrast, the biomass of $P$. piseki was lower than the other dominant species of the genus, only increasing on Cruise 9801.

Other tropical/subtropical oceanic copepods with low contributions to copepod biomass showed interannual differences during fall, but some were higher on Cruise 9710 (Euchaeta indica and Labidocera acutifrons) while others were higher on Cruise 9810 (Acartia danae, Centropages elongatus, Eucalanus hyalinus, Heterorhabdus papilliger and Neocalanus gracilis).

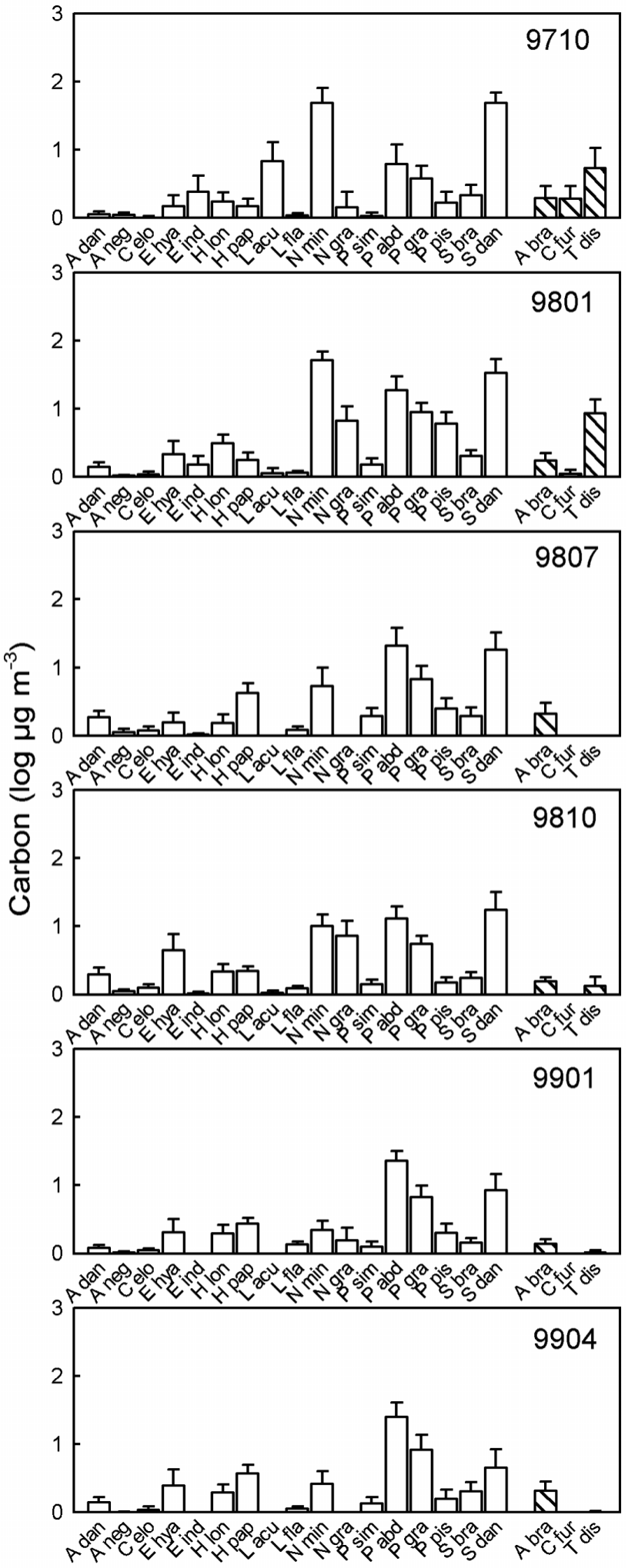

Fig. 8. Carbon biomass (mean $\pm 95 \%$ confidence intervals) of tropical/subtropical copepod species in nighttime samples at IMECOCAL cruises. Hatched bars indicate neritic species; remainder are oceanic. Abbreviations in the abscissa as in Table 2 
However, the response of these species was not consistent in winter excepting for Heterorhabdus papilliger, which could be considered more temperate than tropical as it showed higher abundances on Cruises 9807 and 9904 (July and April respectively). Other minor species with interannual differences during winter were Lucicutia flavicornis, N. gracilis, and Scolecithrix bradyi. The first increased in abundance on Cruise 9901 while the other 2 decreased. The opposite response of $N$. gracilis in fall (Cruise $9710<$ 9810) compared to winter (Cruise $9801>$ 9901) indicates that this species is affected by extreme temperatures.

Apart from Temora discaudata, tropical/ subtropical neritic copepods, had a low biomass through the study period. Centropages furcatus disappeared from July 1998 to April 1999 (Table 2), but Aetideus bradyi persisted with no significant interannual changes.

Warm-temperate group. The most abundant oceanic species during the warm fall of 1997 were 2 species of Euchaeta (Fig. 10). However, while the biomass of E. rimana showed a significant interannual decrease and a reduced abundance in Cruise 9904, E. media was well represented in the cooler cruises (Table 3). The remaining species in this oceanic group showed significant interannual differences only in winter, with increased biomass in January 1999, except for the decrease in Oithona plumifera.

In contrast, the neritic species of this group were better represented in the warm period. Copilia mirabilis, in particular, made a contribution similar to that of the oceanic Euchaeta rimana and exhibited the same progressive decrease after the El Niño peak. Euchaeta longicornis and Corycaeus speciosus also showed significant interannual differences in fall and winter, while the remaining species showed such differences only in fall.

Clausocalanus spp. C. arcuicornis was one of the most abundant species in this genus observed in the samples. This species has a tropical oceanic distribution and has been reported in high abundance in Baja California waters (Fleminger 1964). However, many other Clausocalanus species with a different biogeography occur in the area. Clausocalanus spp. were very abundant during the whole study period
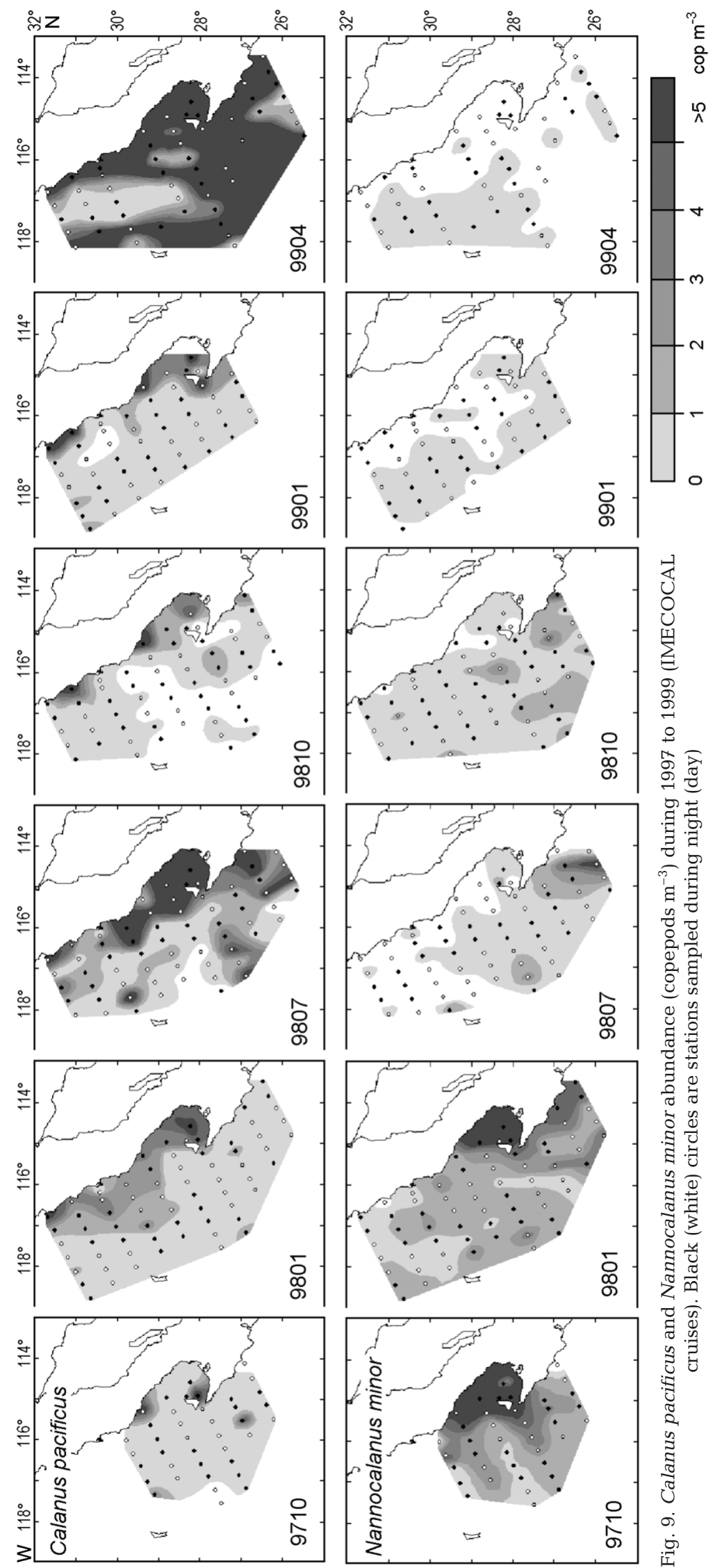

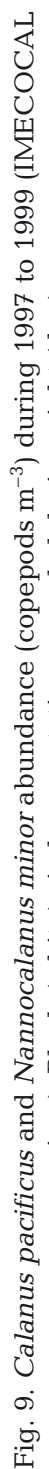




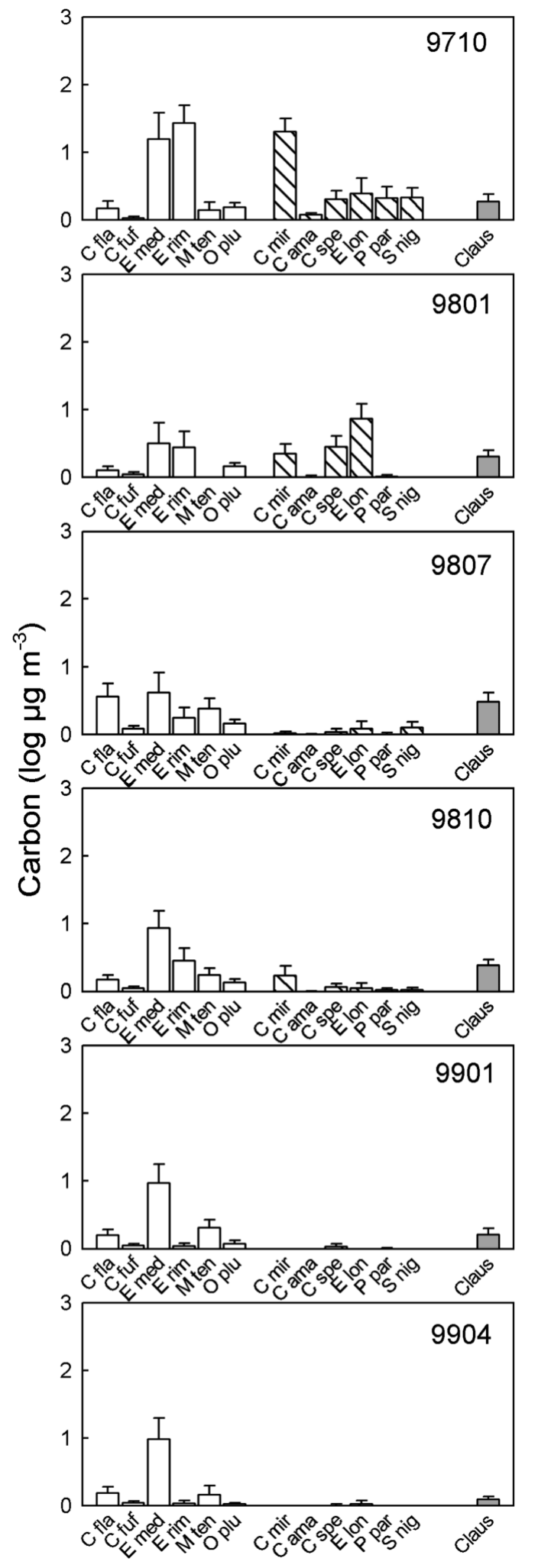

Fig. 10. Carbon biomass (mean $\pm 95 \%$ confidence intervals) of warm-temperate copepod species (white bars) and Clausocalanus (gray bars) in nighttime samples at IMECOCAL cruises. Hatched bars indicate neritic species, remainder are oceanic. Abbreviations in the abscissa as in Table 2
(Table 2), but in fall 1998 copepods of this genus were the most abundant in the community. Because of its small body size (0.8 to $1.6 \mathrm{~mm})$, the amount of biomass represented by this genus is not impressive (Fig. 10). Interannual differences were observed only in fall (Table 3).

\section{Comparison of the 1957-1959 and 1997-1998 El Niño events}

Fleminger $(1964,1967)$ described the distribution of calanoid copepods from April 1958 to January 1959, when another strong El Niño event was in progress. Fleminger's $(1964,1967)$ quantitative distributions shown on contour intervals based on a logarithmic scale, permitted us to make a nonparametric comparison with the dominant calanoid species found in the IMECOCAL cruises. El Niño 1957-1959 peaked in winter 1958 but extended through winter 1959. Therefore it appears reasonable to compare data for fall (CalCOFI Cruise 5810) and winter (CalCOFI Cruise 5901) with data for the same seasons in the IMECOCAL Cruises in 1997-1998.

Species with higher abundance during 1997-1998. All the Equatorial species were more abundant on Cruise 9710 (September-October 1997) than on Cruise 5810 (October 1958) (Table 4). The oceanic Pareucalanus attenuatus, Subeucalanus subtenuis and Undinula darwini invaded Vizcaino Bay during Cruise 9710 and further north. The neritic $S$. pileatus (combined with $S$. subcrassus), although well represented along the coastal area in Cruise 5810, extended more to the west during Cruise 9710. The most marked difference was for $U$. vulgaris, which was completely absent north of transect line 120 on Cruise 5810, but was ubiquitous on Cruise 9710. Similar trends were observed for Equatorial species during winter, except for U. vulgaris, which almost disappeared in Cruise 9801.

The Tropical/subtropical species significantly higher in fall 1997 were Centropages furcatus, Nannocalanus minor, and Scolecithrix danae (Table 4). C. furcatus showed a more extended distribution to the north on Cruise 9710 than on Cruise 5810. N. minor and $S$. danae although present over the whole area during both El Niño events, ranked higher on Cruise 9710. A similar trend was observed in winter. Other species more abundant on Cruise 9801 than in Cruise 5901 were Haloptilus longicornis and Pleuromamma gracilis (the latter combined with $P$. piseki). $H$. longicornis invaded coastal waters along transect line 100 and P. gracilis penetrated Vizcaino Bay on Cruise 9801.

The only species to indicate that the El Niño 1997 1998 event was weaker than the event of 1957-1959 were 2 species from the Transition Zone group, Eucalanus californicus and Rhincalanus nasutus (Table 4). 
Table 4. Comparison of calanoid copepod abundance during 2 strong El Niños, in fall $(5810,9710)$ and winter $(5901,9801)$, using the Mann-Whitney $U$ test. Only species with significant results at $\alpha=0.05$ for one or both seasons are shown ( $\mathrm{n}=10,15,12,28$ for 5810, 9710, 5901, 9801 respectively, NS = not significant)

\begin{tabular}{|c|c|c|c|c|}
\hline \multirow[t]{2}{*}{ Species } & \multicolumn{2}{|c|}{$\begin{array}{c}\text { El Niño fall } \\
\text { (5810 vs } 9710)\end{array}$} & \multicolumn{2}{|c|}{$\begin{array}{l}\text { El Niño winter } \\
\text { (5901 vs 9801) }\end{array}$} \\
\hline & $\mathrm{z}$ & $\mathrm{p}$ & $\mathrm{z}$ & $\mathrm{p}$ \\
\hline & \multicolumn{2}{|c|}{ More abundant in 9710} & \multicolumn{2}{|c|}{ More abundant in 9801} \\
\hline Eucalanus californicus & -2.35 & 0.048 & & NS \\
\hline Rhincalanus nasutus & & NS & -2.99 & 0.003 \\
\hline Pareucalanus attenuatus & -4.17 & $<0.001$ & -5.06 & $<0.001$ \\
\hline Subeucalanus pileatus + subcrassus & $S-3.04$ & 0.003 & -4.03 & 0.001 \\
\hline Subeucalanus subtenuis & -3.04 & 0.004 & -5.03 & $<0.001$ \\
\hline Undinula darwini & -4.44 & $<0.001$ & -4.81 & $<0.001$ \\
\hline Undinula vulgaris & -4.22 & $<0.001$ & & NS \\
\hline Centropages furcatus & -2.92 & 0.012 & & NS \\
\hline Haloptilus longicornis & & NS & -2.35 & 0.033 \\
\hline Nannocalanus minor & -2.40 & 0.023 & & NS \\
\hline Pleuromamma gracilis + piseki & & NS & -2.62 & 0.012 \\
\hline Scolecithrix danae & -3.41 & 0.001 & -3.55 & $<0.001$ \\
\hline \multirow[t]{2}{*}{ Euchaeta rimana } & -2.84 & 0.005 & & NS \\
\hline & \multicolumn{2}{|c|}{ Less abundant in 9710} & \multicolumn{2}{|c|}{ Less abundant in 9801} \\
\hline Metridia pacifica & 3.03 & 0.016 & & NS \\
\hline Candacia bipinnata & 4.03 & $<0.001$ & & NS \\
\hline Pleuromamma borealis & 2.84 & 0.007 & 2.53 & 0.013 \\
\hline Scolecithricella ovata & 2.71 & 0.031 & & NS \\
\hline Acartia negligens & & NS & 2.75 & 0.031 \\
\hline Heterorhabdus papilliger & 2.18 & 0.048 & & NS \\
\hline Lucicutia flavicornis & 3.25 & 0.002 & 2.38 & 0.045 \\
\hline Temora discaudata & 2.24 & 0.031 & & NS \\
\hline Mesocalanus tenuicornis & 2.91 & 0.007 & 5.47 & $<0.001$ \\
\hline Paracalanus parvus & & NS & 5.33 & $<0.001$ \\
\hline
\end{tabular}

The warm-temperate cosmopolites that were better represented in the winter 1959 were Mesocalanus tenuicornis and Paracalanus parvus (Table 4). $M$. tenuicornis was absent from samples during Cruise 9801 (Table 2), while it was broadly distributed in the region on Cruise 5901. P. parvus was also common during Cruise 5901 and was particularly abundant along transect line 120, where it did not occur during Cruise 9801.

\section{DISCUSSION}

The physical evolution of ENSO from the warm phase in 1997-1998 to the cold phase in 1998-1999 has been extensively documented for the Pacific basin (Webster \& Palmer 1997. McPhaden 1999) and in the CCS (Lynn et al. 1998, Collins et al. 2002, Durazo \& Baumgartner 2002, Huyer et al. 2002, Lynn \& Bograd 2002). Particularly relevant for the present study is the analysis by Lynn \& Bograd (2002) for the southern California region. Based on departures of dynamic height and transport from their seasonal norms, these authors considered

The former was absent from the region during Cruise 5810, and the second was very rare on Cruise 5901.

Species with higher abundance during 1958-1959. The subarctic Metridia pacifica and 3 Transition Zone species (Candacia bipinnata, Pleuromamma borealis and Scolecithricella ovata) were more abundant on Cruise 5810 than in Cruise 9710 (Table 4). The intrusion of these species in the Baja California region was higher during fall 1958 (moderately higher for M. pacifica) than in fall 1997. A similar intrusion during winter 1959 was only observed for $P$. borealis, including the invasion of Vizcaino Bay, while in the winter of 1998 was more scattered. The better representation in the region of these species with cold water affinity indicated an El Niño 1958-1959 event less intense than the event of 1997-1998.

Of the tropical/subtropical species 3 ranked higher on Cruise 5810 than on Cruise 9710, but only Lucicutia flavicornis had a similar trend in winter (Cruise 5901 against Cruise 9801) (Table 4). The distribution of this species was more extensive in the region during El Niño 1958-1959, entering in the shallow area of Vizcaino Bay. Acartia negligens also ranked higher on Cruise 5901, being well distributed in the area. that El Niño 1997-1998 showed 2 pulses, one in July 1997 and a second stronger pulse in NovemberDecember 1997. Therefore, our first 2 IMECOCAL cruises (9710 and 9801) which took place before and after the second El Niño pulse are appropriate to characterize the warming event. The abrupt change from a net poleward flow reversing to an equatorward flow was observed in southern California in April 1998, but negative temperature anomalies were not evident until October 1998 (Lynn \& Bograd 2002). This is consistent with the transition to a cooler and fresher state off Baja California from October 1998 to August 1999 (Durazo \& Baumgartner 2002).

During the anomalous warming of 1997-1998, the copepod community off Baja California showed pronunced changes, the most impressive being the increase in abundance of Equatorial species (Pareucalanus attenuatus, Subeucalanus subtenuis, S. pileaEquatorial species, constrained to low latitudes (Fleminger 1973, 1975, Brinton et al. 1986), usually occupy a limited area at the southern edge of the CCS, and are often only evident in autumn and winter (Fleminger 1964, 1967). During the El Niño of 1997-1998, these tus, S. subcrassus, Undinula darwini, and U. vulgaris). 
species expanded their distribution to the complete Baja California sector of the CCS. The group of Tropical/Subtropical species also increased during El Niño. Although the tropical species usually occur in low numbers in subtropical regions, during the warm phase of 1997-1998 they exhibited a strong increase. In particular, Nannocalanus minor was the dominant copepod on Cruise 9710 and the second most dominant on Cruise 9801. The preponderance of the Equatorial and Tropical/Subtropical species off Baja California during El Niño indicated that this was the most perturbed region of the CCS. None of the Equatorial species appeared in the list of 'exotic southern taxa' on transect line $\mathrm{P}$, off Vancouver (Mackas \& Galbraith 2002), neither in the list of warm water species off Oregon (Peterson et al. 2002), or in the list off Monterey Bay (Hopcropft et al. 2002) during El Niño 1997-1998.

Transport by the poleward flow appears to be an important factor accounting for distributional shifts, as illustrated by Undinula vulgaris. Although this species is usually restricted to neritic waters of the eastern tropical Pacific (Fleminger 1975, Suárez-Morales et al. 2000), it was ubiquitous off Baja California during fall 1997 (Fig. 6). The widespread presence of this species through the oceanic area appears to be due to the strong near-surface poleward coastal jet along the peninsula south of Punta Eugenia (Lynn et al. 1998). The coastal jet had disappeared by January 1998, but the poleward flow continued from the southwest, introducing saline (Equatorial) water (Fig. 3b,d) as far as southern California (Lynn \& Bograd 2002). The distribution of Subeucalanus subtenuis during JanuaryFebruary 1998 (Cruise 9801) (Fig. 7) matched remarkably well with $10 \mathrm{~m}$ isohalines, and thus is a useful marker of the strong poleward flow during El Niño. S. subtenuis, an inhabitant of eutrophic oceanic waters (Fleminger 1973), found favorable conditions at moderate chlorophyll concentrations on Cruise 9801 (Lavaniegos et al. 2002). This species is one of the dominant species of the eastern tropical Pacific (Boyd et al. 1980, Arcos \& Fleminger 1986, Chen 1986, FernándezAlamo et al. 2000), and extends offshore along the equator (Grice 1961, Fleminger 1973, Timonin \& Voronina 1977). In the southern hemisphere it is abundant off Peru, but during fall and winter 1997-1998 the presence of expatriate $S$. subtenuis also was noted at Mejillones Bay, Chile (23으) (Hidalgo \& Escribano 2001).

Unfortunately we did not sample in April 1998, when the reversal of flow seems to have occurred in southern California (Lynn \& Bograd 2002). However, by July 1998 the intensification of the California Current was evident in the low-salinity nucleus observed at oceanic stations along transect line 110 (Fig. 3a,c). Again, the transition to cool conditions had a strong effect on the copepod community, with a virtual disappearance of equatorial copepods and a considerable reduction in the Tropical/Subtropical group. At the same time, the abundance of temperate species recovered. While Nannocalanus minor decreased and retreated to oceanic areas, Calanus pacificus became the top calanoid in July 1998 and again in April 1999.

Calanus pacificus showed different responses to El Niño, depending on latitude. Thus, while Peterson et al. (2002) noted an increase in abundance of this species off Oregon, other authors from central (Hopcroft et al. 2002) and southern California (Rebstock 2002) waters recorded a decrease. This is an expected result for a Transition zone species endemic to the California Current that has been displaced northward under warm conditions. However, we do not have sufficient evidence of a negative effect on abundance or biomass of C. pacificus off Baja California. It is well known that this species avoids surface waters from late summer to and early winter (Longhurst 1967, Aldredge et al. 1984, Osgood \& Checkley 1997), i.e. is the time of seasonal warming and decreased primary production. Thus, through a diapause mechanism, C. pacificus probably avoided surface waters during El Niño and attain an advantage after that event; this was particularly marked during the productive spring of 1999 (Lavaniegos et al. 2002). A similar process could have operated in populations of other Transition zone species (Eucalanus californicus, Rhincalanus nasutus) which showed a strong rebound during Cruise 9904 (April 1999). Dormancy of these Transition zone species and the Subarctic Metridia pacifica was analyzed by Ohman et al. (1998), based on metabolic enzymes and lipids. While $M$. pacifica shows no evidence of dormancy, $C$. pacificus has a biphasic life history, with an actively reproducing segment of the population in surface waters overlying a deep dormant segment in winter.

One of the problems inherent in understanding the biological effects of events such as El Niño and La Niña, is the uncertainty about the seasonal norms. The CalCOFI time series has been useful in understanding the physical variability of the CCS on seasonal and interannual scales (Lynn \& Simpson 1987), and even decadal scales inside the southern California region (Bograd \& Lynn 2003). Bowman \& Johnson (1973) described the distribution of some calanoid copepods between May and October 1949, but the southern Baja California region was not included in the first CalCOFI cruises. The distribution charts of Fleminger (1964, 1967) included a more complete number of species and better coverage for the Baja California region. However, his seasonal series was based on cruises in 19581959 (CalCOFI Cruises 5804, 5807, 5810, 5901), at the time when other strong ENSO was taking place.

Increasing evidence of a long-term process of warming in the North Pacific between 1976 and 1998 (Latif \& 
Barnett 1994, Miller et al. 1994, Roemmich \& McGowan 1995, Mantua et al. 1997) and possible persistent cooling since 1999 (Lavaniegos \& Ohman 2003) has renewed interest in possible changes in species composition. A retrospective analysis of the CalCOFI collection from the region off southern California was done by Rebstock $(2001,2002)$ who, from 1951 to 1999 found a consistent dominance of Calanus pacificus, Metridia pacifica and Pleuromamma borealis during spring (Rebstock 2001). Although C. pacificus did not change on decadal scales, it unequivocally decreased in abundance during anomalous years (i.e. El Niño years). It was also the species showing the strongest seasonal change, as a difference of $87 \%$ was found between its abundance in spring and autumn. Among the Tropical/subtropical species enriching the southern California community during fall was Nannocalanus minor, which was relatively abundant during 1997-1998, but was less abundant than the main Transition zone species (Rebstock 2002).

The weak response of Nannocalanus minor in southern California, during fall 1997, contrasts with the strong increase of this species in Baja California waters. The regional differences are sufficiently important and the long-term trends from southern California are not appropriate for resolving interannual perturbations in the Baja California region. The extent of stability of the copepod assemblages off Baja California is still unresolved and needs to be addressed, with an additional analysis of CalCOFI samples. The overwhelming presence of Equatorial species during the El Niño event of 1997-1998 compared to that of 1957-1959 could have 3 possible interpretations: (1) El Niño 1997-1998 was more intense than El Niño 19581959; (2) both events were similar, but climatic influences of different types affected the region during the relevant periods; (3) the comparison was influenced by the deeper sampling $(210 \mathrm{~m})$ in 1997-1998 than in 1957-1958 (140 m).

Certainly the 1957-1959 El Niño event was one of the strongest and longest on record. The classification of Wolter \& Timlin (1998), based on the multivariate ENSO index, ranked the period between May 1957 and May 1958 highest, while that between November 1958 and March 1959 was ranked as moderate. It could be argued that the cruises under comparison (CalCOFI Cruises 5810 and 5901) did not include the warmest phase, which occurred in 1957-1958, and therefore any comparison with recent cruises $(9710,9801)$ would be based on different phases of the ENSO cycle. A more valid comparison would require data from fall 1957 (Cruise 5710) and winter 1958 (Cruise 5801), for which unfortunately there are no data on copepod abundance in the region. An additional complication is the influence superimposed by a different time scale. The warm regime affecting the region during 1977 to 1998 (Mantua et al. 1997) could have induced the intrusion of tropical species. There is biological evidence from ichthyoplankton (Moser et al. 2001) and euphausiids (Brinton \& Townsend 2003) that suggests colonization by tropical species off southern California, or a decline in abundance of some mid-latitude salps (Lavaniegos \& Ohman 2003).

Information for other El Niños is available for Baja California coastal waters. Hernández-Trujillo (1999) reported changes in the copepod community off south Baja California throughout the period 1982 to 1989. The overlap of this area with the IMECOCAL grid is confined to the southern locations near the coast. Although some species were common to El Niño 19821983, El Niño 1987-1988 and El Niño 1997-1998, Nannocalanus minor was one of the most abundant species only during 1987-1988. Subeucalanus subtenuis and $S$. pileatus were not reported in Hernández-Trujillo's (1999) study on previous El Niños, and perhaps were confused with other species of the genus also abundant in the area (Fleminger 1973). In Magdalena Bay $\left(24.5^{\circ} \mathrm{N}, 112^{\circ} \mathrm{W}\right)$, Undinula vulgaris was found during 1983 (Palomares-García \& Gómez-Gutiérrez 1996) and again in 1997-1998 (Palomares-García et al. 2003). The strong predominance of Acartia lilljeborgii and $A$. tonsa in Magdalena Bay may indicate a high degree of avoidance of oceanic waters by these species.

In the Gulf of California during the spring of 1983, Subeucalanus subtenuis and $S$. pileatus were, together with Pleuromamma gracilis, the most abundant calanoids (Jiménez-Pérez \& Lara-Lara 1988). Nannocalanus minor, although present, was less important. Similarly, during El Niño 1992-1993, a replacement of $N$. minor by the neritic $U$. vulgaris was observed in Canal San Lorenzo $\left(24.5^{\circ} \mathrm{N}, 110.33^{\circ} \mathrm{W}\right)$. The differential response of $N$. minor inside the Gulf and $N$. minor off the western coast of Baja California could be due to the oceanic affinity of this species. The entrance to the Gulf is more influenced by eastern tropical Pacific fauna, particularly in autumn/winter, when the Costa Rica Coastal Current develops along the Central American coast (Badan-Dangon 1998). The evolution of this current is not well known. The Costa Rica Coastal Current could reach the coastal zone off western Baja California and may be associated with the coastal jet observed during fall 1997 (Lynn et al. 1998). The North Equatorial Countercurrent (NECC), from which the Costa Rica Coastal Current arises, becomes stronger during the ENSO, as was observed in 19821983 (Dessier \& Donguy 1987). The herbivorous copepods Undinula darwini, N. minor, Clausocalanus spp. and Paracalanus spp. in the NECC domain of the eastern tropical Pacific during El Niño 1982-1983 decreased in abundance, while opposite response was 
observed off Baja California during El Niño 1997-1998 for $U$. darwini and N. minor, which appeared to be forced northward.

In conclusion, the composition of copepods off Baja California during the period 1997 to 1999 showed a rapid transition from an Equatorial-Tropical/subtropical community during El Niño to a temperate or Transition zone community typical of the CCS during La Niña. Seasonal and interannual trends cannot be separated by means of the few historical data available, and require a renewed focus on retrospective studies for the region. The CalCOFI zooplankton collection includes samples from the Baja Californian sector for the period 1949-1984, and the similarity in sampling methods make possible future comparison with the IMECOCAL samples analyzed in the present study.

Acknowledgements. The work at sea of the staff participating in the IMECOCAL cruises is greatly appreciated. Support was provided by the Consejo Nacional de Ciencia y Tecnología (grants G0041-T9607, G3532-GT, and 017PÑ-1297), the Inter-American Institute for Global Change Research (grant ISP 2-124), the Centro de Investigación Científica y Educación Superior de Ensenada (projects Efectos del ENSO 1997-1998 sobre el zooplancton de la Corriente de California and La Niña 1999 y su impacto en el zooplancton de la Corriente de California), and by US GLOBEC (grant OCE 01103000 from NSF and NOAA to M. D. Ohman). Contribution number 425

\section{LITERATURE CITED}

Alldredge AL, Robinson BH, Fleminger A, Torres JJ, King JM, Hamner WM (1984) Direct sampling and in situ observation of a persistent copepod aggregation in the mesopelagic zone of the Santa Barbara Basin. Mar Biol 80: $75-81$

Arcos F, Fleminger A (1986) Distribution of filter-feeding calanoid copepods in the eastern equatorial Pacific. Calif Coop Ocean Fish Invest Rep 27:170-187

Badan-Dangon A (1998) Coastal circulation from the Galápagos to the Gulf of California coastal segment. The Sea 11: 315-343

Barnett AM (1974) The feeding ecology of an omnivorous neritic copepod, Labidocera trispinosa Esterly. PhD dissertation, Scripps Institution of Oceanography, University of California, San Diego, La Jolla, CA

Bograd SJ, Lynn RJ (2003) Long-term variability in the Southern California Current System. Deep-Sea Res II 50: $2355-2370$

Bowman TE, Johnson MW (1973) Distributional atlas of calanoid copepods in the California Current region, 1949 and 1950. Calif Coop Ocean Fish Invest Atlas 19:1-239

Boyd CM, Smith SL, Cowles TJ (1980) Grazing patterns of copepods in the upwelling system off Peru. Limnol Oceanogr 25(4):583-596

Brinton E, Townsend A (2003) Decadal variability in abundances of the dominant euphausiid species in the southern sectors of the California Current. Deep Sea Res II 50: 2449-2472

Brinton E, Fleminger A, Siegel-Causey D (1986) The temper- ate and tropical planktonic biota of the Gulf of California. Calif Coop Ocean Fish Invest Rep 27:228-266

Brodsky KA (1967) Calanoida of the Far Eastern Seas and Polar Basin of USSR. Israel Program for scientific translations, Jerusalem

Brodsky KA (1975) Phylogeny of the family Calanidae (Copepoda) on the basis of a comparative morphological analysis of its characters. In: Zvereva ZA (ed) Geographical and seasonal variability of marine plankton. Israel Program for scientific translations, Jerusalem, p 1-127

Chavez PF, Strutton PG, Friedrich GE, Feely RA, Feldman GC, Foley DG, McPhaden MS (1999) Biological and chemical response of the Equatorial Pacific Ocean to the 199798 El Niño. Science 286:2126-2131

Chavez PF, Pennington JT, Castro CG, Ryan JP, and 6 others (2002) Biological and chemical consequences of the 1997 1998 El Niño in central California waters. Prog Oceanogr $54: 205-232$

Chen Y (1986) The vertical distribution of some pelagic copepods in the Eastern Tropical Pacific. Calif Coop Ocean Fish Invest Rep 27:205-226

Chisholm LA, Roff JC (1990) Size-weight relationships and biomass of tropical neritic copepods off Kingston, Jamaica. Mar Biol 106:71-77

Collins CA, Castro CG, Asanuma H, Rago TA, Han SK, Durazo R, Chavez FP (2002) Changes in the hydrography of Central California waters associated with the 1997-98 El Niño. Prog Oceanogr 54:129-147

Corwith HL, Wheeler PA (2002) El Niño related variations in nutrient and chlorophyll distributions off Oregon. Prog Oceanogr 54:361-380

Dawson KJ, Knatz G (1980) Illustrated key to planktonic copepods of San Pedro Bay, California. Allan Handcock Foundation Tech Rep 2, Los Angeles, CA

Dessier A, Donguy JR (1987) Response to El Niño signals of the epiplanktonic copepod populations in the eastern tropical Pacific. J Geophys Res 92:14393-14403

Durazo R, Baumgartner TR (2002) Evolution of oceanographic conditions off Baja California: 1997-1999. Prog Oceanogr $54: 7-31$

Fernández-Alamo MA, Sanvicente-Añorve L, Alameda-dela-Mora G (2000) Copepod assemblages in the Gulf of Tehuantepec, Mexico. Crustaceana 73:1139-1153

Fleminger A (1964) Distributional atlas of calanoid copepods in the California Current region, part I. Calif Coop Ocean Fish Invest Atlas 2:1-313

Fleminger A (1967) Distributional atlas of calanoid copepods in the California Current region, part II. Calif Coop Ocean Fish Invest Atlas 7:1-213

Fleminger A (1973) Pattern, number, variability and taxonomic significance of integumental organs (sensilla and glandular pores) in the genus Eucalanus (Copepoda: Calanoida). Fish Bull 71:965-1010

Fleminger A (1975) Geographical distribution and morphological divergence in American coastal-zone planktonic copepods of the genus Labidocera. In: Cronin LE (ed) Estuarine research Vol. 1: Chemistry, biology and the estuarine system. Academic Press, New York, p 392-419

Geletin YV (1976) The ontogenetic abdomen formation in copepods of genera Eucalanus and Rhincalanus (Calanoida, Eucalanidae) and new system of these copepods. Issledov-aniya Fauny Morei 18:75-93

Goetze E (2003) Cryptic speciation on the high seas; global phylogenetics of the copepod family Eucalanidae. Proc Roy Soc Lond B 270:2321-2331

Grice DG (1961) Calanoid copepods from equatorial waters of the Pacific Ocean. Fish Bull US 61:167-246 
Hayward LT (2000) El Niño 1997-98 in the coastal waters of southern California: a timeline of events. Calif Coop Ocean Fish Invest Rep 41:98-116

Hayward LT, Baumgartner TR, Checkley DM, and 8 others (1999) The state of the California Current in 1998-1999: transition to cool-water conditions. Calif Coop Ocean Fish Invest Rep 40:29-62

Hernández-Trujillo S (1999) Variability of community structure of Copepoda related to El Niño 1982-83 and 1987-88 along the west coast of Baja California peninsula, México. Fish Oceanogr 8:284-295

Hickey B (1979) The California current system: hypothesis and facts. Prog Oceanogr 8:191-279

Hidalgo P, Escribano R (2001) Succession of pelagic copepod species in coastal waters off northern Chile: the influence of the 1997-98 El Niño. Hydrobiologia 453/454:153-160

Hopcroft RR, Roff JC, Lombard D (1998) Production of tropical copepods in Kingston Harbour, Jamaica: the importance of small species. Mar Biol 130:593-604

Hopcroft RR, Clarke C, Chavez FP (2002) Copepod communities in Monterey Bay during the 1997-1999 El Niño and La Niña. Prog Oceanogr 54:251-264

Huyer A, Smith RL, Fleischbein J (2002) The coastal ocean off Oregon and northern California during the 1997-8 El Niño. Prog Oceanogr 54:311-341

Jiménez-Pérez LC, Lara-Lara JR (1988) Zooplankton biomass and copepod community structure in the Gulf of California during the 1982-1983 El Niño event. Calif Coop Ocean Fish Invest Rep 29:122-128

Kahru M, Mitchell G (2000) Influence of the 1997-98 El Niño on the surface chlorophyll in the California Current. Geophys Res Lett 27:2937-2940

Latif M, Barnett TP (1994) Causes of decadal climate variability over the North Pacific and North America. Science 266: 634-637

Lavaniegos BE, Ohman MD (2003) Long-term changes in pelagic tunicates in the California Current. Deep Sea Res II 50:2473-2498

Lavaniegos BE, Jiménez-Pérez LC, Gaxiola-Castro G (2002) Plankton Response to El Niño 97-98 and La Niña 99 in the Southern region of the California Current. Prog Oceanogr 54:33-58

Lindley JA, John AWG, Robins DB (1997) Dry weight, carbon and nitrogen content of some calanoid copepods from the seas around southern Britain in winter. J Mar Biol Assoc UK 77:249-252

Longhurst AR (1967) Vetical distribution of zooplankton in relation to the easthern Pacific oxygen minimum. DeepSea Res 14:51-63

Lynn RJ, Simpson JJ (1987) The California Current system: the seasonal variability of physical characteristics. J Geophys Res 92:12947-12966

Lynn RJ, Bograd SJ (2002) Dynamic evolution of the 1997 1999 El Niño-La Niña cycle in the southern California Current System. Prog Oceanogr 54:59-75

Lynn RJ, Bliss KA, Eber LE (1982) Vertical and horizontal distributions of seasonal mean temperature, salinity, sigma-t, stability, dynamic height, oxygen and oxygen saturation in the California Current, 1950-1978. Calif Coop Ocean Fish Invest Atlas 30:1-513

Lynn RJ, Baumgartner T, García J, Collins CA, and 8 others (1998) The state of the California Current, 1997-1998: Transition to El Niño conditions. Calif Coop Ocean Fish Invest Rep 39:25-49

Mackas DL, Galbraith M (2002) Zooplankton community composition along the inner portion of Line P during the 1997-1998 El Niño event. Prog Oceanogr 54:423-437
Mantua NJ, Hare SR, Zhang Y, Wallace JM, Francis RC (1997) A Pacific interdecadal climate oscillation with impacts on salmon production. Bull Am Meteorol Soc 78:1069-1079

Marinovic BB, Croll DA, Gong N, Benson SR, Chavez FP (2002) Effects of the 1997-1999 El Niño and La Niña events on zooplankton abundance and euphausiid community composition within the Monterey Bay coastal upwelling system. Prog Oceanogr 54:265-277

McPhaden JM (1999) Genesis and evolution of the 1997-98 El Niño. Science 283:950-954

McPhaden JM, Yu X (1999) Equatorial waves and the 1997-98 El Niño. Geophys Res Lett 26:2961-2964

Miller AJ, Cayan DR, Barnett TP, Graham NE, Oberhuber JM (1994) The 1976-1977 climate shift of the Pacific Ocean. Oceanography 7(1):21-26

Moser HG, Charter RL, Smith PE, Ambrose DA, Watson W, Charter SR, Sandknop EM (2001) Distributional atlas of fish larvae and eggs in the Southern California Bight region: 1951-1998. Calif Coop Ocean Fish Invest Atlas 34: $1-166$

Mullin MM, Brooks ER (1967) Laboratory culture, growth rate and feeding behavior of a planktonic marine copepod. Limnol Oceanogr 12:657-666

Nishida S (1985) Taxonomy and distribution of the family Oithonidae (Copepoda, Cyclopoida) in the Pacific and Indian Oceans. Bull Ocean Res Inst, Univ Tokyo 20:1-167

Ohman MD (1988) Sources of variability in measurements of copepod lipids and gut fluorescence in the California Current coastal zone. Mar Ecol Prog Ser 42:143-153

Ohman MD, Drits AV, Clarke ME, Plourde S (1998) Differential dormancy of co-occurring copepods. Deep Sea Res II 45:1709-1740

Osgood KE, Checkley DM Jr (1997) Seasonal variations in a deep aggregation of Calanus pacificus in the Santa Barbara basin. Mar Ecol Prog Ser 148:59-69

Palomares-García R, Gómez-Gutierrez J (1996) Copepod community structure at Bahia Magdalena, Mexico during the El Niño 1983-1984. Estuar Coast Shelf Sci 43:583-595

Palomares R, Suárez-Morales E, Hernández-Trujillo S (1998) Catálogo de los copépodos (crustácea) pelágicos del Pacífico Mexicano. Centro Interdisciplinario de Ciencias Marinas/Colegio de la Frontera Sur, México

Palomares-García R, Martínez-López A, De-Silva-Dávila R, Funes-Rodríguez R, Carballido-Carranza MA, AvendañoIbarra R, Hinojosa-Medina A, López-Ibarra GA (2003) Biological effects of El Niño 1997-98 on a shallow subtropical ecosystem: Bahía Magdalena, Mexico. Geofisica Internacional 42(3):455-466

Park TS (1968) Calanoid copepods from the central North Pacific ocean. Fish Bull 66:527-572

Park TS (1995) Taxonomy and distribution of the marine calanoid copepod family Euchaetidae. Bull Scripps Inst Oceanogr 1-203

Peterson WT, Keister JE, Feinberg LR (2002) The effects of the 1997-99 El Niño/La Niña events on hydrography and zooplankton off the central Oregon coast. Prog Oceanogr 54: 381-398

Rebstock GA (2001) Long-term stability of species composition in calanoid copepods off southern California. Mar Ecol Prog Ser 215:213-224

Rebstock GA (2002) Climatic regime shifts and decadal scale variability in calanoid copepod populations off southern California. Global Change Biol 8:71-89

Roemmich D, McGowan J (1995) Climatic warming and the decline of zooplankton in the California Current. Science 267:1324-1326

Runge JA (1980) Effects of hunger and season on the feeding 
behavior of Calanus pacificus. Limnol Oceanogr 25: 134-145

Satapoomin S (1999) Carbon content of some common tropical Andaman Sea copepods. J Plankton Res 21:2117-2123

Schwing FB, Moore CS, Ralston S, Sakuma KM (2000) Record coastal upwelling in the California Current in 1999. Calif Coop Oceanic Fish Inves Rep 41:148-160

Smith PE, Richardson S (1977) Standard techniques for pelagic fish eggs and larvae surveys. FAO Fish Tech 175: $1-100$

Suárez-Morales E, Franco-Gordo C, Saucedo-Lozano M (2000) On the pelagic copepod community of the central Mexican tropical Pacific (Autumn, 1990). Crustaceana 73(6): $751-761$

Takayabu YN, Iguchi T, Kachi M, Shibata A, Kanzawa H (1999) Abrupt termination of the 1997-98 El Niño in response to a Madden-Julian oscillation. Nature 402: 279-282

Tanasichuk RW, Cooper C (2002) A northern extension of the range of the euphausiid Nyctiphanes simplex into Canadian waters. J Crustac Biol 22:206-209

Tester PA, Turner JT (1988) Comparative carbon-specific ingestion rates of phytoplankton by Acartia tonsa, Centropages velificatus and Eucalanus pileatus grazing on natural phytoplankton assemblages in the plume of the Mississippi River (northern Gulf of Mexico continental shelf). Hydrobiologia 167-168:211-217

Timonin AG, Voronina MN (1977) Net plankton distribution along the equator in the eastern Pacific Ocean. Pol Arch Hydrobiol 24 (Suppl):281-305

US GLOBEC (1994) Eastern Boundary Current Program. A science plan for the California Current. Rep 11, US GLOBEC Office, University of California, Berkeley, CA

Uye S (1982) Length-weight relationships of important zooplankton from the inland Sea of Japan. J Oceanogr Soc Japan 38:149-158

Webber MK, Roff JC (1995) Annual biomass and production of the oceanic copepod community off Discovery Bay. Mar Biol 123:481-495

Webster PJ, Palmer TN (1997) The past and the future of El Niño. Nature 390:562-564

Whitney FA, Welch DW (2002) Impact of the 1997-1998 El Niño and 1999 La Niña on nutrient supply in the Gulf of Alaska. Prog Oceanogr 54:405-421

Wilkerson FP, Dugdale RC, Marchi A, Collins CA (2002) Hydrography, nutrients and chlorophyll during El Niño and La Niña 1997-99 winters in the Gulf of the Farallones, California. Prog Oceanogr 54:293-310

Wolter K, Timlin MS (1998) Measuring the strength of the ENSO events: How does 1997-98 rank? Weather 53: 315-324

Yamaguchi A, Ikeda T (2000) Vertical distribution, life cycle and body allometry of two oceanic calanoid copepods (Pleuromamma scutullata and Heterorhabdus tanneri) in the Oyashio region, western north Pacific Ocean. J Plankton Res 22:29-46

Appendix 1. Copepod species present (+) during 1997 to 1999 El Niño and La Niña

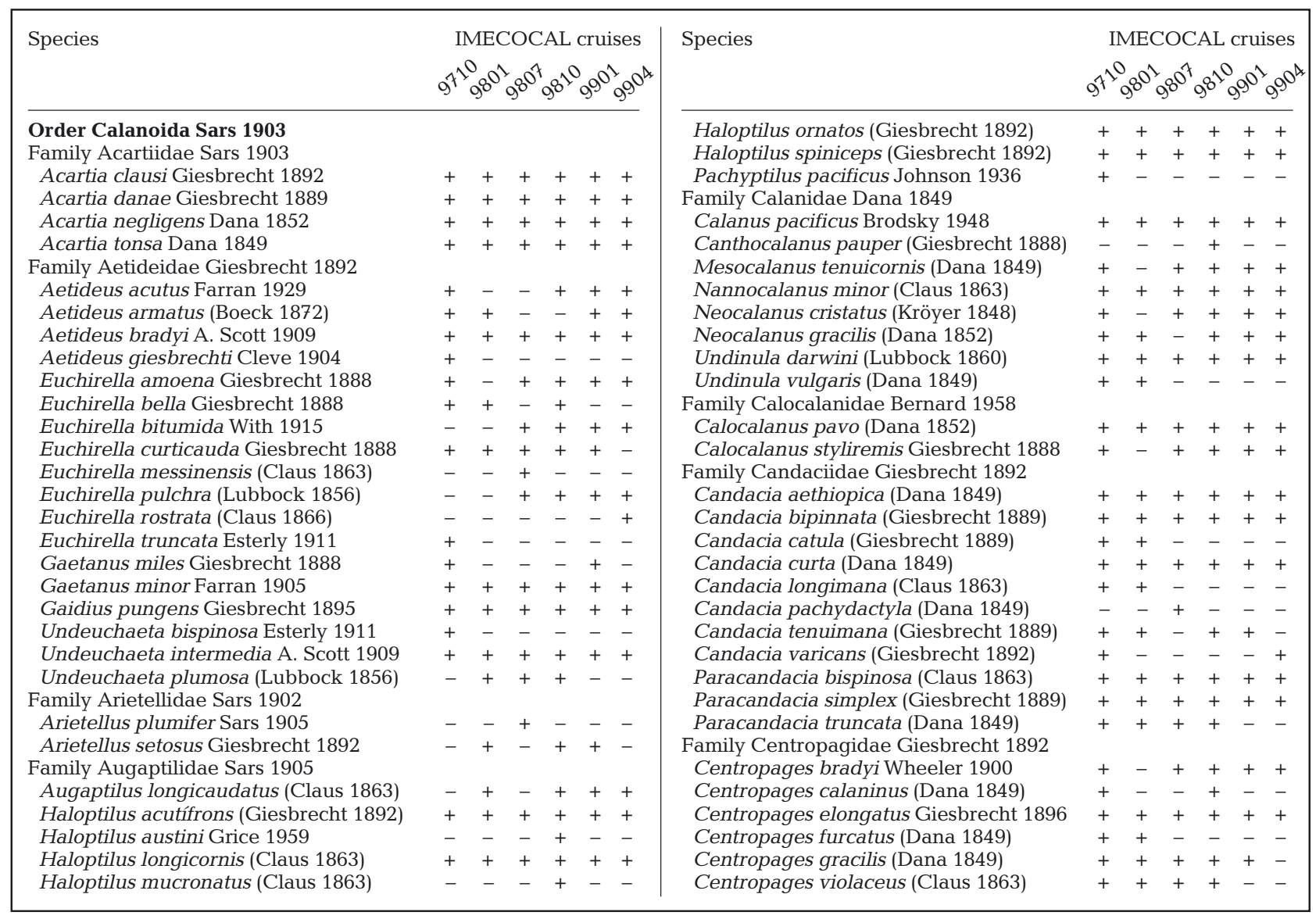




\begin{tabular}{|c|c|c|c|c|c|c|c|c|c|c|c|c|c|}
\hline \multirow{2}{*}{$\begin{array}{l}\text { Species } \\
\text { Family Clausocalanidae Giesbrecht } 1892\end{array}$} & \multicolumn{6}{|c|}{ 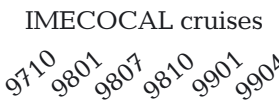 } & \multirow{2}{*}{$\begin{array}{l}\text { Species } \\
\text { Scottocalanus securifrons (T. Scott 1894) }\end{array}$} & \multicolumn{6}{|c|}{ 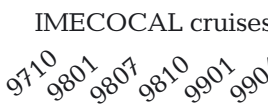 } \\
\hline & & & & & & & & - & & & & & \\
\hline Clausocalanus spp. & + & + & + & + & + & + & Scottocalanus sedatus Farran 1936 & + & & + & + & + & \\
\hline Family Eucalanidae Giesbrecht 1892 & & & & & & & Family Temoridae Giesbrecht 1892 & & & & & & \\
\hline Eucalanus californicus Johnson 1938 & + & + & + & + & + & + & Temora discaudata Giesbrecht 1889 & + & + & + & + & + & + \\
\hline Eucalanus elongatus (Dana 1849) & - & - & - & + & - & + & Family Tortanidae Sars 1902 & & & & & & \\
\hline Eucalanus hyalinus (Claus 1866) & + & + & + & + & + & + & Tortanus discaudatus (Herdman, & & & & & & \\
\hline Pareucalanus attenuatus (Dana 1849) & + & + & + & + & + & + & Thompson \& A. Scott 1897) & - & - & - & - & + & - \\
\hline Subeucalanus crassus Giesbrecht 1888 & + & - & - & - & - & - & Order Cyclopoida Burmeister 1835 & & & & & & \\
\hline Subeucalanus mucronatus Giesbrecht 1888 & + & - & - & & - & & Family Oithonidae Dana 1852 & & & & & & \\
\hline Subeucalanus pileatus Giesbrecht 1888 & + & + & + & + & - & + & Oithona attenuata Farran 1913 & - & + & - & + & + & - \\
\hline Subeucalanus subcrassus Giesbrecht 1888 & + & + & + & + & + & + & Oithona oculata Farran 1913 & - & - & - & + & + & - \\
\hline Subeucalanus subtenuis Giesbrecht 1888 & + & & + & + & + & + & Oithona plumifera Baird 1843 & + & + & + & + & + & + \\
\hline Rhincalanus nasutus Giesbrecht 1888 & + & + & + & + & + & + & Oithona similis Claus 1866 & + & + & + & + & - & - \\
\hline Family Euchaetidae Giesbrecht 1892 & & & & & & & Oithona spinirostris Claus 1863 & + & + & - & + & + & \\
\hline Euchaeta acuta Giesbrecht 1892 & + & + & - & + & - & - & Oithona tenuis Rosendorn 1917 & - & - & + & - & + & - \\
\hline $\begin{array}{l}\text { Euchaeta concinna Dana } 1849 \\
\text { Euchaeta indica Wolfenden } 1905\end{array}$ & + & - & - & - & - & - & Order Harpacticoida Sars 1903 & & & & & & \\
\hline $\begin{array}{l}\text { Euchaeta indica Woltenden } 1905 \\
\text { Euchaeta longicornis Giesbrecht } 1888\end{array}$ & $\begin{array}{l}+ \\
+\end{array}$ & $\begin{array}{l}+ \\
+\end{array}$ & $\begin{array}{l}+ \\
+\end{array}$ & $\begin{array}{l}+ \\
+\end{array}$ & $\begin{array}{c}- \\
+\end{array}$ & $\begin{array}{l}- \\
+\end{array}$ & Family Clytemnestridae A. Scott 1909 & - & - & - & - & - & - \\
\hline Euchaeta media Giesbrecht 1888 & + & & + & + & + & + & Clytemnestra rostrata (Brady 1883) & - & - & + & - & & \\
\hline Euchaeta rimana Bradford 1974 & + & & + & + & + & + & Family Ectinosomatidae Sars 1903 & & & & & & \\
\hline Euchaeta spinosa Giesbrecht 1892 & + & - & - & + & + & - & Microsetella rosea (Dana 1849) & - & + & + & + & + & - \\
\hline Euchaeta tenuis Esterly 1906 & + & + & + & + & + & - & Order Poecillostomatoida Thorell 1859 & & & & & & \\
\hline Paraeuchaeta elongata (Esterly 1913) & + & - & - & - & - & - & Family Corycaeidae Dana 1852 & & & & & & \\
\hline Family Heterorhabdidae Sars 1902 & & & & & & & Corycaeus agilis Dana 1849 & - & - & - & + & - & - \\
\hline Heterorhabdus clausi (Giesbrecht 1889) & - & - & - & + & - & - & Corycaeus amazonicus F. Dahl 1894 & + & + & + & + & - & - \\
\hline Heterorhabdus papilliger (Claus 1863) & + & + & + & + & + & + & Corycaeus americanus Wilson 1949 & + & + & - & - & - & - \\
\hline Heterorhabdus spinifrons (Claus 1863) & + & + & + & + & + & + & Corycaeus anglicus Lubbock 1857 & + & + & - & - & - & - \\
\hline Heterorhabdus tanneri (Giesbrecht 1895) & + & + & - & - & + & - & Corycaeus clausi F. Dahl 1894 & - & + & + & + & + & - \\
\hline Heterostylites longicornis (Giesbrecht 1889) & + & + & - & + & + & + & Corycaeus crassiusculus Dana 1849 & - & - & - & + & - & + \\
\hline Family Lucicutiidae Sars 1902 & & & & & & & Corycaeus flaccus Giesbrecht 1891 & + & + & + & + & + & + \\
\hline Lucicutia flavicornis (Claus 1863) & + & & + & + & + & + & Corycaeus furcifer (Claus 1863) & + & + & + & + & + & + \\
\hline Family Mecynoceridae Andronov 1973 & & & & & & & Corycaeus giesbrechti F. Dahl 1894 & + & - & - & - & + & - \\
\hline Mecynocera clausi Thompson 1888 & + & + & + & + & + & + & Corycaeus gracilis Dana 1849 & - & + & - & - & - & - \\
\hline Family Metridinidae Sars 1902 & & & & & & & Corycaeus latus Dana 1849 & + & - & - & - & - & - \\
\hline Gaussia princeps (T. Scott 1894) & - & - & + & + & + & - & Corycaeus lautus Dana 1849 & + & + & + & + & + & + \\
\hline Metridia pacifica Brodsky 1950 & + & + & + & + & + & + & Corycaeus limbatus Brady 1883 & - & + & + & + & + & + \\
\hline Metridia princeps Giesbrecht 1889 & - & - & - & + & + & + & Corycaeus longistylis Dana 1849 & - & - & - & + & - & - \\
\hline Pleuromamma abdominales (Lubbock 1856) & + & + & + & + & + & + & Corycaeus pacificus F. Dahl 1894 & + & + & + & + & - & - \\
\hline Pleuromamma borealis (F. Dahl 1893) & + & + & + & + & + & + & Corycaeus robustus Giesbrecht 1892 & + & - & - & - & - & - \\
\hline Pleuromamma gracilis (Claus 1863) & + & + & + & + & + & + & Corycaeus speciosus Dana 1849 & + & + & + & + & + & + \\
\hline Pleuromamma piseki Farran 1929 & + & + & + & + & + & + & Farranula gibbula (Giesbrecht 1891) & - & - & - & - & + & - \\
\hline Pleuromamma quadrungulata (F. Dahl 1893) & + & + & + & + & + & + & Farranula gracilis (Dana 1849) & - & + & - & - & - & - \\
\hline Pleurommama xiphias (Giesbrecht 1889) & + & + & + & + & + & + & Family Oncaeidae Giesbrecht 1892 & & & & & & \\
\hline Family Paracalanidae Giesbrecht 1892 & & & & & & & Conaea rapax Giesbrecht 1891 & - & - & - & + & - & - \\
\hline Acrocalanus longicornis Giesbrecht 1888 & + & - & - & + & - & - & Lubbockia aculeata Giesbrecht 1891 & - & - & - & + & - & + \\
\hline Paracalanus parvus (Claus 1863) & + & + & + & + & + & - & Lubbockia squillimana Claus 1863 & - & - & - & - & + & - \\
\hline Family Phaennidae Sars 1902 & & & & & & & Oncaea confiera Giesbrecht 1891 & + & - & - & + & - & - \\
\hline Amallophora smithae Grice 1961 & - & + & - & - & - & - & Oncaea dentipes Giesbrecht 1891 & + & + & - & - & - & \\
\hline Phaenna spinifera Claus 1863 & + & + & + & + & + & + & Oncaea media Giesbrecht 1891 & + & + & + & + & + & + \\
\hline Family Pontellidae Dana 1852 & & & & & & & Oncaea mediterranea (Claus 1863) & - & - & + & + & + & - \\
\hline Labidocera acuta (Dana 1849) & + & + & - & - & - & - & Oncaea venusta Philippi 1843 & + & + & + & - & - & - \\
\hline Labidocera acutifrons (Dana 1849) & + & + & - & + & - & - & Pachos punctatum (Claus 1863) & - & - & + & + & + & - \\
\hline Labidocera euchaeta Giesbrecht 1889 & + & + & + & + & - & - & Family Sapphirinidae Thorell 1859 & & & & & & \\
\hline Labidocera jollae Esterly 1906 & - & - & - & - & + & - & Copilia longistylis Mori 1932 & - & - & - & + & - & - \\
\hline Labidocera trispinosa Esterly 1905 & - & - & + & + & - & - & Copilia mirabilis Dana 1852 & + & + & + & + & + & \\
\hline Pontellina plumata (Dana 1849) & + & + & + & + & + & + & Copilia quadrata Dana 1849 & + & + & + & + & + & + \\
\hline Pontellopsis brevis (Giesbrecht 1889) & - & - & - & + & - & - & Copilia recta Giesbrecht 1891 & + & + & - & + & - & - \\
\hline Pontellopsis occidentales Esterly 1906 & + & - & - & + & + & + & Copilia vitrea (Haeckel 1864) & - & - & - & + & - & - \\
\hline Pontellopsis regalis (Dana 1849) & + & - & - & + & - & - & Sapphirina angusta Dana 1849 & - & + & + & + & + & + \\
\hline Family Scolecithricidae Giesbrecht 1892 & & & & & & & Sapphirina darwinii Haeckel 1864 & + & + & + & + & + & \\
\hline Lophotrix frontalis Giesbrecht 1895 & + & + & + & + & + & + & Sapphirina gastrica Giesbrecht 1891 & + & + & + & + & + & + \\
\hline Scaphocalanus magnus (T. Scott 1894) & + & - & - & - & - & - & Sapphirina gemma Dana 1852 & + & + & + & + & + & + \\
\hline Scolecithricella abyssalis (Giesbrecht 1888) & + & + & + & + & + & - & Sapphirina intestinata Giesbrecht 1891 & + & + & + & + & + & \\
\hline Scolecithricella dentata (Giesbrecht 1892) & + & + & + & + & + & + & Sapphirina metallina Dana 1849 & + & + & + & + & - & + \\
\hline Scolecithricella ovata (Farran 1905) & + & + & + & + & + & + & Sapphirina nigromaculata Claus 1863 & + & + & + & + & - & \\
\hline Scolecithrix bradyi Giesbrecht 1888 & + & + & + & + & + & + & Sapphirina opalina Dana 1849 & + & + & + & + & - & + \\
\hline Scolecithrix danae (Lubbock 1856) & + & + & + & + & + & + & Sapphirina scarlata Giesbrecht 1891 & - & + & + & + & + & + \\
\hline Scottocalanus helenae (Lubbock 1856) & - & - & + & + & - & - & Sapphirina stellata Giesbrecht 1891 & + & + & + & + & + & + \\
\hline
\end{tabular}

